NBER WORKING PAPER SERIES

\title{
CONFLICTS OF INTERESTS AMONG SHAREHOLDERS: THE CASE OF CORPORATE ACQUISITIONS
}

\author{
Jarrad Harford \\ Dirk Jenter \\ Kai Li \\ Working Paper 13274 \\ http://www.nber.org/papers/w13274 \\ NATIONAL BUREAU OF ECONOMIC RESEARCH \\ 1050 Massachusetts Avenue \\ Cambridge, MA 02138 \\ July 2007
}

We thank Nittai Bergman, Murray Carlson, Alex Edmans, Adlai Fisher, Ron Giammarino, Jon Karpoff, Alan Kraus, Kalina Manova, Gregor Matvos, Wayne Mikkelson, Pablo Moran, Hernan Ortiz-Molina, Michael Ostrovsky, Jon Reuter, Frederik Schlingemann, Jeremy Stein, Ralph Walkling, and seminar and conference participants at Bentley College, Boston College, Concordia, the MIT finance lunch, Rutgers University, Simon Fraser University, Tsinghua University, the University of British Columbia, the University of Texas at Austin, the University of Toronto, York University, the Pacific Northwest Finance Conference (Seattle), the 13th Mitsui Life Symposium on Value Creation at the University of Michigan (Ann Arbor), and the 2007 Western Finance Association Meetings (Big Sky) for useful comments and discussions. We acknowledge the financial support from the Social Sciences and Humanities Research Council of Canada. All remaining errors are our own. The views expressed herein are those of the author(s) and do not necessarily reflect the views of the National Bureau of Economic Research.

(C) 2007 by Jarrad Harford, Dirk Jenter, and Kai Li. All rights reserved. Short sections of text, not to exceed two paragraphs, may be quoted without explicit permission provided that full credit, including (C) notice, is given to the source. 
Conflicts of Interests Among Shareholders: The Case of Corporate Acquisitions

Jarrad Harford, Dirk Jenter, and Kai Li

NBER Working Paper No. 13274

July 2007

JEL No. G30,G34

\begin{abstract}
$\underline{\text { ABSTRACT }}$
We identify important conflicts of interests among shareholders and examine their effects on corporate decisions. When a firm is considering an action that affects other firms in its shareholders' portfolios, shareholders with heterogeneous portfolios may disagree about whether to proceed. This effect is measurable and potentially large in the case of corporate acquisitions, where bidder shareholders with holdings in the target want management to maximize a weighted average of both firms' equity values. Empirically, we show that such cross-holdings are large for a significant group of institutional shareholders in the average acquisition and for a majority of institutional shareholders in a significant number of deals. We find evidence that managers consider cross-holdings when identifying potential targets and that they trade off cross-holdings with synergies when selecting them. Overall, we conclude that conflicts of interests among shareholders are sizeable and, at least in the case of acquisitions, affect managerial decisions.
\end{abstract}

Jarrad Harford

University of Washington Business School

Box 353200

Seattle, WA 98195-3200

jarrad@u.washington.edu

Dirk Jenter

MIT Sloan School of Management

50 Memorial Drive

Cambridge, MA 02142

and NBER

djenter@mit.edu
Kai Li

Sauder School of Business

University of British Columbia

2053 Main Mall

Vancouver, BC V6T 1Z2

kai.li@sauder.ubc.ca 
Much of the corporate finance literature makes the assumption that (homogenous) shareholders want to maximize the value of their firm's equity. In reality, most shareholders are diversified and care about the effects of managerial actions on their portfolio values, not just on the value of the specific firm taking the action. When shareholders have different portfolios, they may disagree about which actions managers should take. In acquisitions, diversified shareholders who hold equity stakes in both a bidder and its target — cross-holdings for short — want bidder management to maximize a weighted average of the bidder's and the target's equity values. Concentrated shareholders with stakes in only the bidder want management to focus on the bidder's equity value, setting-up a conflict between shareholder groups.

Managers must choose how to act in the presence of shareholders with heterogeneous portfolios. They could ignore this heterogeneity and simply align themselves with concentrated shareholders. Alternatively, they could take it into account in an attempt to maximize the wealth of most stockholders, or they could opportunistically use it to lower shareholder resistance to empire-building acquisitions. In this study, we first measure the extent of shareholder crossholdings and then test for their impact on target choice and deal characteristics to determine whether managers incorporate cross-holdings into their acquisition decisions.

The insight that cross-holdings by shareholders alter their preferences over takeover decisions is a special case of the general result that diversified shareholders prefer corporate policies which maximize their portfolio values to policies which narrowly maximize the values of individual firms (Hansen and Lott (1996); Rubin (2006)). In general, however, externalities on other firms imposed by managers' decisions are likely to be small or hard to estimate, so in a bounded-rationality framework, it makes sense for managers to focus on own firm value. In corporate acquisitions, one of the externalities is large and easily computed, and hence the opportunity to maximize the wealth of the majority (but not simultaneously all) of the shareholders is present. Thus, we use merger bids as our experimental setting and specifically 
test the hypothesis that cross-holdings by bidder shareholders affect target selection and deal structure.

A shareholder who owns equity in both a bidder and its target is concerned with the effect of a takeover bid on both firms' stock prices. We formally show that each shareholder's preferences are determined by the ratio of her percentage stake in the target to her percentage stake in the bidder. This ratio, which we call the bidder shareholder's cross-holding, fully captures the objective function each shareholder wants bidder management to use. In particular, each shareholder wants bidder management to act as if the bidding firm itself owned a toehold equal to that shareholder's cross-holding in the target. In all models of takeover bidding with toeholds considered in the prior literature, toeholds make bidders more willing to pursue an acquisition and to bid aggressively. Bidding firms that consider their shareholders' crossholdings are therefore expected to follow a more aggressive acquisition strategy, and crossholdings should make a given target more attractive to bidders.

The predicted effect of cross-holdings on observable bidding strategies and bid outcomes is more ambiguous. Under the null hypothesis that cross-holdings have an effect on mergers, managers will choose targets that have high cross-holdings, high synergies, or both. Thus, among targets with high cross-holdings, some will also have high synergies, but many will not. Although the direct effect of cross-holdings would be to increase premiums and completion likelihoods, the fact that they may signal low synergies produces an indirect opposite effect. As a result, while cross-holdings should have an observable effect on target selection and bidder announcement returns, the predicted effect on premiums and deal completion is ambiguous.

Bidder managers who want to take their shareholders' cross-holdings into consideration face the challenge that different shareholders have different cross-holdings in the target, with many bidder shareholders holding no shares in the target at all. The heterogeneity in investors' cross-holdings leads to disagreements about the objective function for the bidding firm, and it is far from obvious which decision rule managers should adopt. We therefore use several measures 
of shareholder preferences in the empirical analysis. Two intuitively appealing solutions to the aggregation problem are for managers to maximize a weighted average of shareholder preferences, or for management to simply adopt the preferences of its median shareholder. The median shareholder in our context is defined such that 50 percent of the bidder's shares are held by shareholders with smaller cross-holdings and 50 percent by shareholders with larger crossholdings. Since larger cross-holdings are associated with preferences for a more aggressive acquisition strategy, the median shareholder defines the most aggressive policy a bidder can pursue while maintaining the support of a majority of its shareholders' votes.

We document the magnitude of investor cross-holdings and the resulting conflicts of interests using takeover data and information on the portfolios of large institutional investors from 1984 to 2002 . We show that the average bidder's median institutional shareholder has a cross-holding of 5.3 percent in the target, with a median of 0.0 percent. ${ }^{1}$ The distribution of cross-holdings is strongly right-skewed both across bidders and across shareholders in a given bidder; in five percent of the bidders, the median institution has cross-holdings of more than 40 percent in the target. In the average bidder, 20 percent of the institutional holdings are by investors with cross-holdings of more than 34 percent, and 10 percent of the institutional holdings are by investors with cross-holdings of more than 74 percent. Hence many institutional investors want bidder management to act as if the bidder had a large toehold in the target, which in turn implies substantial disagreements between shareholders with cross-holdings and those without. We compute the effect of these cross-holdings on the total abnormal returns experienced by institutional investors around the bids, including the effect of the bid on the target's stock price. We find that the median institution averages a positive 0.2 percent return improvement, or about 17 percent of the average bidder announcement return of -1.2 percent.

\footnotetext{
${ }^{1}$ The median institutional shareholder is defined such that $50 \%$ of the institutional ownership in the bidder is by institutions with larger cross-holdings and $50 \%$ by institutions with smaller cross-holdings. This definition is similar to the definition of the median shareholder discussed before, with all percentiles re-defined relative to the total institutional ownership in the firm.
} 
We find that cross-holdings by bidder shareholders are important in the choice of takeover targets. Target firms have significantly higher cross-holdings by bidder shareholders than do non-target control firms. Further, consistent with our conjecture that bidders trade off cross-holdings with synergies when selecting acquisition targets, we find that high crossholdings are associated with low post-acquisition operating performance. There is no observable effect of cross-holdings on bid premiums or deal completion probabilities, which supports the conjecture that any direct effect of cross-holdings on the aggressiveness of bidding strategies is mitigated by an indirect selection effect associating cross-holdings with low synergies. Finally, we do not find evidence that managers are using cross-holdings to facilitate empire-building acquisitions. We conclude that the conflicts of interests between diversified and concentrated shareholders in mergers are pervasive enough to matter, and that managers pay attention to the cross-holdings of their diversified shareholders.

In related work, Matvos and Ostrovsky (2006) argue that investor cross-holdings may explain the low and often negative returns to acquiring firms in takeovers. They argue that bidder shareholders with large cross-holdings do not mind overpaying for targets, and hence that crossholdings help explain why shareholders fail to block apparently bad takeover deals. Different from our work, they do not analyze individual cross-holdings and instead add up bidder shareholders' stakes in the target. This approach aggregates away the conflicts between shareholders with heterogeneous cross-holdings. Our analysis clarifies that each shareholder's preferences are determined by her relative holdings in the bidder and the target, and that only shareholders who own a larger percentage of the target than of the acquirer favor overpayment. Empirically, shareholders with cross-holdings above 100 percent are rare and hold on average only 4.1 percent of the bidders' equity in our data. Hence the influence of investors who favor 
overpayment is likely to be limited, and cross-holdings are unlikely to explain why bidders overpay. $^{2}$

The plan of the paper is as follows. The next section draws on prior theoretical work on toeholds to formally analyze the effects of cross-holdings on firms' objectives, and to develop our null hypothesis and some testable implications. Section II describes our data and the variable definitions used in the empirical analysis. Section III presents summary statistics on the size and prevalence of cross-holdings in actual takeovers and examines their effects on target selection, announcement returns, takeover premiums, and the probability of takeover success. The last section summarizes and concludes.

\section{Theoretical Background and Hypothesis Development}

This section examines how cross-holdings affect shareholders' preferences over mergers and acquisitions, and how bidder management may react to the heterogeneous preferences of its shareholders. We first analyze shareholder preferences in the two canonical classes of takeover models examined in the prior literature, models of tender offers in the spirit of Grossman and Hart (1980) and models of competitive takeover bidding in the spirit of Fishman (1988). We then present our null hypothesis and its testable implications.

\footnotetext{
${ }^{2}$ Matvos and Ostrovsky (2006) also show that mutual funds that hold shares in both a bidder and its target are more likely to vote for mergers with negative announcement returns. This finding suggests that institutional investors do pay attention to interactions between the firms in their portfolios. There has also been other work on shareholder conflicts. Eckbo and Verma (1994) identify shareholder conflicts over dividend policy due to heterogeneous tax rates, information asymmetries, and agency costs. Rice (2006) demonstrates that the importance of a shareholder group to price formation depends on the group's price elasticity of demand for shares, leading to a divergence between the effects of corporate decisions on market values and the effects of those decisions on shareholder welfare. Kraus and Rubin (2007) show that the conflict between diversified shareholders who want to maximize their portfolio values and managers who use capital budgeting rules to choose firm-value maximizing projects has important implications for executive compensation design.
} 


\section{I.A. Cross-holdings in a model of tender offers with free-riding}

This section describes shareholder preferences in a Grossman and Hart (1980)-type setting with dispersed target shareholders. Consider a model with two firms, a bidder and a target. The bidder is able to create synergies worth $S>0$ that are realized only if the bidder acquires control. To obtain control, the bidder needs to acquire 50 percent of the target shares in a conditional tender offer, which entails a transaction cost of $k>0$. Assume that $S>k$ so that the acquisition is socially efficient. All target shares are held by dispersed shareholders.

In Grossman and Hart, atomistic target shareholders do not tender their shares at any price below the full post-takeover value since their own tendering decision is irrelevant for the outcome of the tender offer. The result is that all synergies $S$ accrue to target shareholders, while bidder shareholders incur the transaction cost $k$. Now consider the preferences of a shareholder who owns $\alpha_{B}$ percent of the bidder and $\alpha_{T}$ percent of the target. This shareholder wants the bidder to pursue an acquisition whenever her share of the associated takeover gains exceeds her share of the takeover costs:

$$
\alpha_{T} \cdot S>\alpha_{B} \cdot k \Leftrightarrow-k+\left(\frac{\alpha_{T}}{\alpha_{B}}\right) \cdot S>0
$$

The shareholder wants bidder management to put a weight of $\left(\alpha_{T} / \alpha_{B}\right)$ on target value and to effectively internalize $\left(\alpha_{T} / \alpha_{B}\right)$ percent of the takeover gains accruing to target shareholders. But the decision rule in (1) is simply the optimal rule for a value-maximizing bidding firm that owns a toehold of $\left(\alpha_{T} / \alpha_{B}\right)$ percent in the target (see for example, Shleifer and Vishny (1986), Hirshleifer and Titman (1990), and Chowdhry and Jegadeesh (1994)). Hence a bidder shareholder with relative cross-holdings of $\left(\alpha_{T} / \alpha_{B}\right)$ wants bidder management to act as if the bidder itself had a toehold of $\left(\alpha_{T} / \alpha_{B}\right)$. In the extreme, a shareholder who owns a higher 
percentage of the target than of the bidder and thus has a cross-holding larger than 100 percent would benefit from overpayment for the target. ${ }^{3}$

\section{I.B. Cross-holdings in a model of competitive takeover bidding}

This section examines shareholder preferences in models in which two or more bidders compete for a target, and in which the Grossman-Hart free-rider problem plays no role. Most papers in this literature use an "ascending clock" auction, in which the bid price is gradually increased and the bidders choose whether to remain in the auction or to drop out. The last remaining bidder wins and has to pay the price at which the second-to-last bidder withdrew. For simplicity, we assume that there are only two bidders, labeled 1 and 2, and that both bidders are risk neutral. Let $V_{i}$ denote the private value of the target to bidder $i$, and assume that both $V_{l}$ and $V_{2}$ exceed the value of the target under current management. Bidder 1's and bidder 2's strategies consist of choosing price ceilings $C_{1}$ and $C_{2}$, respectively, at which to withdraw from the auction, given that the rival is still bidding. The winning bidder is obligated to accept all tendered shares, including any toehold shares tendered by the rival bidder. Target shareholders tender their shares to the auction winner as long as the final price exceeds the value of the target under incumbent management.

Now consider the preferences of a shareholder who owns $\alpha_{B}$ percent of bidder 1 and $\alpha_{T}$ percent of the target. This shareholder receives $\alpha_{B}$ percent of any takeover gains accruing to bidder 1 in case bidder 1 wins the auction, and the shareholder sells her $\alpha_{T}$ percent target stake at the winning price to whichever bidder wins the auction. Hence her expected payoffs are given by:

\footnotetext{
${ }^{3}$ It may seem surprising that shareholder preferences are independent of the size of the bidder relative to the target. However, this result obtains because the impact of a larger relative bidder value on the shareholder's wealth $\left(\alpha_{B} V_{B}\right)$ is exactly offset by the smaller effect on the bidder value due to overpaying for a relatively smaller target. Intuitively, a shareholder with stakes in both firms simply receives $\alpha_{B}$ percent of any takeover gains accruing to the bidder and $\alpha_{T}$ percent of any gains accruing to the target, independently of the relative sizes of the two firms.
} 
$\operatorname{Pr}($ bidder 1 wins $) \cdot\left[\alpha_{B} \cdot\left(V_{1}-E\left(C_{2} \mid\right.\right.\right.$ bidder 1 wins $\left.)\right)+\alpha_{T} \cdot E\left(C_{2} \mid\right.$ bidder 1 wins $\left.)\right]+\operatorname{Pr}($ bidder 2 wins $) \cdot\left[\alpha_{T} \cdot C_{1}\right]$ $\Rightarrow$

$\operatorname{Pr}($ bidder 1 wins $) \cdot\left[V_{1}-E\left(C_{2} \mid\right.\right.$ bidder 1 wins $)+\left(\frac{\alpha_{T}}{\alpha_{B}}\right) \cdot E\left(C_{2} \mid\right.$ bidder 1 wins $\left.)\right]+\operatorname{Pr}($ bidder 2 wins $) \cdot\left[\left(\frac{\alpha_{T}}{\alpha_{B}}\right) \cdot C_{1}\right]$

The payoff function puts a relative weight of one on the takeover gains to bidder 1 in case that bidder wins, and a relative weight of $\left(\alpha_{T} / \alpha_{B}\right)$ on the takeover price paid, independently of which bidder wins. But this is exactly the objective function of a bidding firm that owns a toehold of $\left(\alpha_{T} / \alpha_{B}\right)$ percent in the target and sells that toehold in case a rival wins the auction (Burkhart (1995); Singh (1998)).

To summarize, we have shown that both in free-rider models based on Grossman and Hart (1980) and in models of competitive bidding based on Fishman (1988) and Burkhart (1995), a shareholder with percentage stakes $\alpha_{B}$ in the bidder and $\alpha_{T}$ in the target wants bidder management to act as if the bidder itself owned a toehold of size $\left(\alpha_{T} / \alpha_{B}\right)$. This motivates our focus on the distribution of these cross-holdings among bidder shareholders in Section III.

\section{I.C. Aggregation of shareholder preferences by bidder management}

The cross-holdings are by construction shareholder-specific and range from zero to above 100 percent in most bidder-target combinations. Bidder management thus faces the question of how to aggregate the preferences of its shareholders into a decision rule for the overall firm. Even if we assume that bidder managers wish to maximize the welfare of their shareholders, it is far from obvious what acquisition strategy managers should adopt since any strategy has to favor the preferences of one set of shareholders over others. Theory provides little guidance as to how bidder management should aggregate its shareholders' preferences, and what weight to attach to the target value in its objective function. Two intuitively appealing solutions to the aggregation problem are for managers to adopt the preferences of its median shareholder, or for managers to maximize a weighted average of shareholder preferences. 
Under the median-shareholder criterion, bidder management pursues all takeover deals which are supported by the owners of a majority of its shares. The median shareholder is defined such that 50 percent of bidder shares are held by investors with larger cross-holdings and 50 percent by investors with smaller cross-holdings. Since larger cross-holdings make a shareholder prefer a more aggressive acquisition strategy, the median shareholder defines the most aggressive strategy managers can implement while retaining the support of a majority of shareholders' votes.

The median-shareholder criterion by design ignores the preferences of most shareholders. Alternatively, bidder managers may try to maximize a weighted average of all their shareholders' subjective preferences. While it is not obvious what weights management should use to aggregate shareholder preferences, most reasonable weighting schemes would imply that bidders shift to a more aggressive acquisition strategy even if only 10 or 20 percent of their shareholders have equity stakes in a target. ${ }^{4}$ In Section III, we document both the preferences of the median shareholder and of the subsets of bidder shareholders with the highest cross-holdings, and examine whether their preferences are reflected in acquisitions.

Cross-holdings will only affect real-world acquisitions if bidder management does in fact consider the portfolios of its shareholders, or if diversified shareholders have the means to impose portfolio-value maximization on management. A priori, there are several reasons to expect that managers may ignore the cross-holdings their shareholders have in other firms. Large concentrated shareholders such as founding families or venture capitalists are unlikely to own any cross-holdings in target firms, but are likely to be active in corporate governance and to exert influence over managers. Further, the compensation of top executives is heavily biased towards stock options and restricted stock and thus ultimately depends on own-firm performance

\footnotetext{
${ }^{4}$ Drèze (1974) uses shareholders' ownership stakes as weights to aggregate heterogeneous shareholder preferences. Interestingly, applying this weighting scheme to cross-holdings amounts to simply adding up the bidder shareholders' percentage stakes in the target, and hence yields aggregate preferences as if there were a perfect coalition among bidder shareholders. This degree of coordination between shareholders is not realistic and we opt not to use this aggregation scheme in the empirical analysis. We do, however, consider the possibility that the largest institutional shareholders may align their preferences through negotiated side-payments.
} 
(Murphy (1999)). ${ }^{5}$ Hence managers are given strong incentives to maximize the performance of their own firm, but few obvious incentives to care about any externalities they impose on other firms in their shareholders' portfolios.

The degree to which cross-holdings will matter thus depends on the ability of crossholding investors to influence bidder management. Shareholders with cross-holdings may be able to influence acquisition decisions through their representatives on boards of directors, voting at shareholders' meetings, or private or public communication with the management team (Smith (1996); Carleton, Nelson, and Weisbach (1998)). This kind of influence is most likely for institutional investors and for blockholders, which are therefore the focus of our empirical analysis. Whether bidder management takes its shareholders' portfolios into account is ultimately an empirical question which we attempt to answer in Section III.

\section{I.D. Hypothesis development and testable implications}

Our null hypothesis is that bidder managers take their shareholders' cross-holdings into account in target selection and structuring deals, while our alternative hypothesis is that crossholdings have no effect on mergers. Assuming that the null hypothesis prevails, how would the bidder's acquisition strategy change? In Grossman and Hart (1980), a toehold bidder receives some of the takeover gains accruing to target shareholders, making it more likely that the bidder is able to cover the acquisition cost and hence more likely that the bid goes ahead. Crossholdings by bidder shareholders in a target should thus make an acquisition bid more likely. Hence, we expect:

- Testable Implication 1: There is a positive association between cross-holdings by a bidder's shareholders and, ceteris paribus, the likelihood that a firm will be targeted by that bidder.

\footnotetext{
${ }^{5}$ This raises the question of why managerial contracts are written this way to begin with. While beyond the scope of this paper, we offer the following considerations. First, incentives are endogenous and negotiated between managers and the board. If concentrated shareholders dominate corporate governance and boards, then incentive contracts will reflect their preferences. Second, moving away from firm-value maximization as the objective function in designing executive compensation schemes may have costs, e.g., create more opportunities for managers to maximize their own welfare at the expense of shareholders.
} 
In models of competitive takeover bidding, a toehold makes it optimal for a bidder to bid more aggressively and to even raise its bid above its own valuation for the target. The more aggressive bidding strategy increases the bidder's expected capital gain on the toehold should a rival win and purchase the toehold. Hirshleifer and Titman (1990), and Chowdhry and Jegadeesh (1994) conclude that the probability of takeover success increases in the size of the bidder's toehold. Cross-holdings by bidder shareholders in a target should therefore motivate bidder management to bid more aggressively.

Empirically, however, we only observe the net effect of cross-holdings on target selection and on bid aggressiveness. If firms select targets by trading off cross-holdings with synergies, then a substantial fraction of targets with high cross-holdings will have lower than average synergies. ${ }^{6}$ To the extent that we are unable to perfectly measure synergies, this confounds our analysis. For example, a bid where a high premium is paid for a target with low synergies and high bidder shareholder cross-holdings may be indistinguishable from a bid where a normal premium is paid for a target with high synergies and low shareholder cross-holdings. Moreover, the benefits of more aggressive bidding accrue only to bidder shareholders with cross-holdings and not to the bidding firm itself. We predict:

- Testable Implication 2: Ceteris paribus, there is a negative association between crossholdings and synergies.

- Testable Implication 3: The net effects of cross-holdings on premiums and completion rates are ambiguous, while their effect on bidder announcement returns is negative.

Under the null hypothesis, bidder managers may choose to take their shareholders' crossholdings into account for the opportunistic purpose of reducing their resistance to empirebuilding acquisitions. If the motivation is management driven, then we would still expect to see an effect of cross-holdings in target selection, but not necessarily in bid characteristics. More importantly, we would expect to see this type of managerial behavior concentrated in poorly

\footnotetext{
${ }^{6}$ Based on the same argument, Shleifer and Vishny (1986) and Hirshleifer and Titman (1990) show that toeholds are associated with lower bid premiums as toeholds allow acquisitions with lower value-added to proceed.
} 
governed firms. Empirically, if agency problems drive the effect of cross-holdings on target selection, we expect:

- Testable Implication 4: There is a positive association between cross-holdings and poor governance in the bidding firm.

\section{Sample Formation and Variable Construction}

\section{II.A. Sample selection}

We begin with all announced (both completed and cancelled) US mergers with announcement dates between January 1, 1984 and December 31, 2002 as identified from the Mergers and Acquisitions database of the Securities Data Company (SDC). We identify all deals where both the bidder and the target are public firms and the form of deal was coded as a merger, an acquisition of majority interest, or an acquisition of assets. After applying the above filters, we get 8,075 deals. The sample period is chosen because the information in SDC is less reliable before 1984 and we require data on post-merger performance.

Next, we match our bidders and targets with Compustat and CRSP data, and only retain an acquisition if the bidder owns less than 50 percent of the target prior to the bid and is seeking to own greater than 50 percent after the bid. For completed deals, we require that the bidder owns more than 90 percent of the target after the deal completion. These filters yield 2,885 deals.

Finally, we merge our acquisition data with the CDA/Spectrum $13 \mathrm{~F}$ data on institutional shareholdings in the bidder and the target. ${ }^{7}$ Ideally, we would also like to measure cross-holdings at the individual investor level. Using data on institutional investors adds a layer of intermediation between individual investors and firms, and makes it difficult to assess the extent to which the ultimate owners of the assets are diversified across firms. However, given the greater size of their stakes, the cross-holdings of institutional investors are more likely to be

\footnotetext{
${ }^{7}$ A 1978 amendment to the Securities and Exchange Act of 1934 requires all institutions with greater than $\$ 100$ million of equity securities under discretionary management to report every quarter all common-stock positions greater than 10,000 shares or $\$ 200,000$ using the SEC's form 13F.
} 
reflected in company policies than the cross-holdings of individuals. When interpreting our results it is nevertheless useful to keep in mind that we do not observe the portfolios of noninstitutional investors and therefore miss potentially significant cross-holdings. In a similar vain, an institutional portfolio reported to the SEC may be an aggregate of multiple distinct portfolios managed by the institution, adding noise to our measure of cross-holdings. Our final sample has 2,815 merger deals where both the bidder and the target have data on institutional shareholdings in the quarter-end prior to the bid announcement.

\section{II.B. Variable construction}

From Section I we know that bidder shareholders' preferences are determined by their cross-holdings, defined as their percentage ownership of the target divided by their percentage ownership of the bidder. Since different shareholders have different cross-holdings, their preferences over acquisitions are heterogeneous. We therefore adopt three complementary approaches to describing the distribution of cross-holdings across shareholders. Given that we do not observe the portfolios of non-institutional investors, we focus most of our discussion on the cross-holdings of institutional investors and restrict our sample to bidders that have at least 20 percent of their equity owned by institutions. This restriction excludes firms in which institutional investors are unlikely to have any influence on management.

The first approach to measuring shareholder preferences captures what percentage of the institutional holdings in the bidder is by investors with large cross-holdings, and what percentage by investors with small or no cross-holdings. Figure 1 illustrates the approach. Specifically, we order all institutional investors in the bidder by their cross-holdings, and then calculate the (marginal) cross-holding for the top 1, 5, 10, 20, and 50 percent of institutional shareholdings (labeled as the top-1\%, top-5\%, top-10\%, top-20\%, and median cross-holdings, respectively). For example, a top-10\% cross-holding of 75 percent means that 10 percent of the institutional ownership in the bidder is controlled by investors with cross-holdings of at least 75 percent. Of 
particular interest is the cross-holding of the median institutional shareholder in the bidder. This median cross-holding determines the set of acquisition policies the bidder can pursue while maintaining the support of the majority of its institutional shareholders' votes. To complement the analysis for institutional shareholders, we also calculate and report cross-holdings for all shareholders of the bidder by making the conservative assumption that all non-institutional investors have zero cross-holdings.

The above approach to measuring cross-holdings ignores the fact that shareholders differ greatly in their ability to impose their preferences on bidder management. We expect management to be most responsive to the preferences of its largest shareholders; hence our next two approaches look explicitly at the cross-holdings of blockholders, defined as institutional investors who own at least five percent of the bidder's shares. Specifically, we order the blockholders by their cross-holdings, and then report the (marginal) cross-holding for the top 5, $10,20,50,75$, and 100 percent of all shares owned by blockholders, in parallel to the calculations for all institutional investors described above.

Finally, we consider the possibility that blockholders might coordinate their actions and negotiate side-payments with each other. With costless bargaining, the Coase Theorem (Coase (1960)) predicts that the blockholders should act in unison and support any acquisition that is profitable for all blockholders combined. The aggregate preferences of any coordinated group of investors are determined by their combined cross-holdings, given by the sum of their equity stakes in the target divided by the sum of their stakes in the bidder. In reality, coordination between blockholders may not be costless and side-payments are likely to be restricted by law. ${ }^{8}$ Hence the blockholders' combined cross-holdings should be interpreted as an upper bound on the cross-holding the blockholders may bring to bear on the bidding firm's decision process.

\footnotetext{
8 The Securities and Exchange Commission passed new rules in 1992 allowing shareholders to directly communicate with each other (SEC (1992)). Thus, the costs of creating shareholder coalitions were substantially reduced.
} 


\section{Empirical Results}

In this section, we first present an overview of our sample with a focus on the magnitude of shareholder cross-holdings. Then, we formally test the null hypothesis that shareholder crossholdings do matter in target selection and present evidence on the effect of cross-holdings on post-merger operating performance. Finally, we examine the role of cross-holdings in determining bid characteristics and outcomes in a multivariate regression framework, and explore alternative explanations to our findings.

\section{III.A. Sample overview}

Table 1 presents descriptive statistics on the announced merger deals, the bidders, and the targets. In Panel A, we show that 75 percent of the announced deals are eventually completed. A quarter of the deals use only cash as the method of payment, and over 40 percent of the deals are pure stock swaps. Approximately 13 percent of the targets receive competing bids within one year. The sample is split evenly between diversifying and within-industry deals. The mean relative deal size, defined as the ratio of the transaction value to the market value of the bidder, is 30 percent. Consistent with the prior literature, there are few direct toeholds, and more than 95 percent of the bidders have no toehold at all in their targets. On average, the bidder is offering a premium of 45 percent above the market price of the target as of four weeks before the bid.

In Panel B, we show that the average three-day abnormal announcement period return (CAR3) for the bidder is -1.2 percent, while the average CAR3 for the target is close to 20 percent. Following Bradley, Desai, and Kim (1988), we also compute the dollar amount of the synergistic gains $(=$ bidder CAR $3 \times$ bidder market capitalization $+\operatorname{target}$ CAR $3 \times(1-$ toehold $) \times$ target market capitalization) as well as the percentage synergy gains (= synergy in dollars $/($ bidder market capitalization $+(1-$ toehold $) \times$ target market capitalization $)$. Panel B shows that the average synergies amount to about $\$ 47$ million in 2002 dollars, corresponding to an average 
percentage gain of about 2 percent. This implies that, once we account for the large positive announcement return to the target, mergers in our sample are on average welfare-improving.

Panels C and D present summary statistics on the bidders and targets in our sample, respectively. Consistent with the relative size variable, the bidders are much larger than their targets in terms of both book and market values. The bidders and targets have similar levels of leverage, while the bidders appear to enjoy faster sales growth, better operating performance, and higher stock returns in the year prior to the bid.

Table 2 presents summary statistics of institutional shareholdings in the bidders and targets. On average, institutional investors own 46 percent of the equity of bidding firms and 32 percent of the equity of targets. Bidder institutions that also own shares in the target control 14 percent of all bidder shares, or 31 percent of the bidder shares owned by institutions. While target institutions that also own shares in the bidder control a similar 18 percent of all target shares, they own over half of the generally smaller institutional holdings in the target.

\section{III.B. The size and pervasiveness of cross-holdings}

Table 3 summarizes the empirical distribution of cross-holdings in the bidders and targets. In Part I of Panel A, we calculate cross-holdings for the top 1, 5, 10, 20, and 50 percent of the bidders' institutional shareholders and limit our sample to bidders with total institutional ownership no less than 20 percent. This reduces our sample by only 16 percent to 2,356 observations. We find that the average cross-holding by the median institutional shareholder is 5.3 percent, with a median of 0.0 percent. The distribution of cross-holdings across bidders is strongly right-skewed; in five percent of the bidders, the median institution has cross-holdings of at least 40 percent, and in one percent of the bidders, the median cross-holding is at least 87 percent. Focusing on the largest cross-holdings, we find that the average top-10\% cross-holding is 75 percent, and that the average top-5\% cross-holding is 140 percent. 
In Part II of Panel A, we calculate cross-holdings for the top 1, 5, 10, 20, and 50 percent of all bidder shareholders, assuming that the cross-holdings of non-institutional investors are zero. With this assumption, we find that the average median cross-holding is only 0.3 percent. This low number is a direct result of the assumed zero cross-holdings for non-institutional investors and of the fact that the median shareholder is an institution in less than half of the bidders in our sample. However, even under these assumptions, the average top- $10 \%$ crossholding is 30 percent. We also compute the fraction of bidder shares whose holders own a higher percentage stake of the target than of the bidder. We find that bidder shareholders with crossholdings greater than one are rare and control on average only 4.1 percent of the bidder's equity and only 10.1 percent of the total institutional holdings in the bidder. This means that the influence of shareholders who favor actual overpayment for the target is likely to be small.

We conclude that there is a substantial number of institutional investors with large crossholdings in the average bidder, and that there is a significant set of mergers in which even the median institution owns a large stake in the target. At the same time, many institutional shareholders of the bidder have no cross-holdings in the target at all, implying significant conflicts of interests over the objective function of the bidder.

The above analysis ignores the differences in the power of different shareholders to impose their preferences on bidder management. We therefore focus next on large shareholders. Table 4 presents summary statistics of cross-holdings held by blockholders, defined as institutions that own at least five percent of the shares of a firm. Part I of Panel A shows that the average cross-holding by the median blockholder is 11 percent (median 0.0 percent), and that in five percent of the bidders, the median blockholder has a cross-holding of 82 percent or more in the target. Turning to blockholders with large cross-holdings, the average top- $20 \%$ cross-holding exceeds 18 percent, and the average top- $10 \%$ cross-holding is almost 20 percent. These numbers suggest that there is a significant number of institutional blockholders, the subset of institutional investors most likely to influence bidder management, with large cross-holdings in the target. 
In Part II of Panel A we examine what would happen if blockholders were to negotiate side-payments with one another and act as a group. The average combined cross-holding by all blockholders in the bidder is 12 percent. The distribution is again skewed, with the median of the combined cross-holding equal to zero. In ten percent of all deals, however, blockholders want management to act as if the bidder had a 46 percent toehold in the target, and in five percent of all deals as if the bidder had a 69 percent toehold in the target. For comparison, Betton, Eckbo, and Thorburn (2005) analyze toeholds held directly by acquirers in a comprehensive sample of twelve thousand bidders and find that only 11 percent of the bidders own any toehold in the target. In their sample, the average toehold size among bidders with a positive toehold is 21 percent, with a median of 17 percent. $^{9}$

Of course, target shareholders can have cross-holdings in the bidder as well, so Tables 3 and 4 present analogous information for target shareholders' cross-holdings in the bidder. We find similar, but generally higher cross-holdings held by target shareholders in the bidder. This is likely a mechanical outcome driven by the relatively greater institutional interest in bidders observed in Table 2 .

\section{III.C. Wealth effects of bid announcements}

Next we examine to what extent the wealth effects of takeovers on bidder shareholders change when we take their cross-holdings in the target into account. To address that question, we introduce the concept of a return improvement. First define the total abnormal announcement return for an institutional investor in a bidder as

$$
\text { Total Abnormal Announcement Return }=\alpha_{B i} \cdot \Delta V_{B}+\alpha_{T i} \cdot \Delta V_{T}
$$

where $\alpha$ is the percentage shareholding by institution $i$ in either the bidder (subscript $B$ ) or in the target (subscript $T$ ) and $\Delta V$ is the abnormal change in firm value, computed as the product of the

\footnotetext{
${ }^{9}$ Similar, if somewhat higher, numbers have been documented before by, among others, Bradley, Desai, and Kim (1988), Jarrell and Poulsen (1989), Jennings and Mazzeo (1993), and Betton and Eckbo (2000).
} 
bidder's or target's market value and the corresponding abnormal announcement period return. The return improvement is the difference between the total abnormal announcement return and the bidder abnormal announcement period return. This measure thus captures the improvement in return experienced by a given bidder shareholder due to her ownership stake in the target.

Table 5 presents the return improvement for institutional investors in the bidder, ordered once more by the size of their cross-holdings. Part I limits the sample to bidders with total institutional ownership no less than 20 percent. We find that the average return improvement for the median institutional shareholder is 0.2 percent, with a median of 0.0 percent. The distribution of return improvement is somewhat skewed; in five percent of the bidders, the median institution has a return improvement of 1.7 percent or better, while in one percent of the bidders, the median institution has a return improvement of 6.2 percent or better. Focusing on bidder institutions with large cross-holdings, we find that the average return improvement for the institution with the top$10 \%$ cross-holding is 2.5 percent; for the institution with the top-5\% cross-holding, it is 3.7 percent. As a reference point, the average bidder announcement return in our sample is -1.2 percent (see Table 1, Panel B). ${ }^{10}$ Thus, we conclude that, in general, the return improvement provided by cross-holdings is moderate, but that in some cases, it is large relative to the average announcement effect.

Part II of Table 5 presents the return improvement for all shareholders, assuming individual shareholders have zero cross-holdings. There remain moderate improvements across bidder shareholders with non-trivial cross-holdings, although as expected the improvements are not as big as those in Panel A.

\footnotetext{
${ }^{10}$ These fairly modest return improvements are a direct consequence of the fact that most targets are small relative to their acquirers; the median relative deal size, which is the ratio of transaction value to market value of the bidder, is only 10 percent. In untabulated analysis, we calculate return improvements for bids whose relative deal size is in the top quartile of all bids. Not surprisingly, the average return improvements are substantially larger for this subset of bids and reach 6.3 percent for the institution with the top- $10 \%$ cross-holding and 8.4 percent for the top-5\% crossholding.
} 


\section{D. The effect of cross-holdings on target selection}

In the next three sub-sections, we formally examine the null hypothesis that managers account for their shareholders' cross-holdings when making decisions about acquisitions. The literature on toeholds has shown that the presence of a toehold increases the bidding likelihood, so we start our investigation by examining the role of cross-holdings in target selection. To examine the first testable implication of our null hypothesis, we compare the cross-holdings of bidder shareholders in the actually chosen targets to their cross-holdings in a sample of alternative targets that were not chosen.

Our control sample of potential target firms is obtained by first identifying the set of all CRSP/Compustat firms that were neither targets nor bidders in our merger sample and that have institutional shareholding data available from CDA. This forms the base set of potential control firms. For each actual target in our sample, we select a control firm from its Fama-French (1997) industry that is closest in market capitalization (requiring that the difference does not exceed 25 percent of the sample firm market capitalization) at the fiscal year-end prior to the bid announcement. ${ }^{11}$ Matching is done with replacement and only one control firm is matched to each sample firm. We are able to match 2,427 control firms to target firms in our sample. We refer to the matching firms as potential targets.

In Table 6, Panel A, we present summary statistics for the potential targets, which can be compared to the corresponding statistics for the actual targets presented in Table 1, Panel D. There is no statistical difference between the actual and potential target samples across most firm characteristics, including the extent of institutional shareholding. This suggests that we have found valid control firms for the targets. The only significant difference between the potential and actual target firms is that the potential targets tend to have higher market-to-book ratios.

Table 6, Panel B presents the empirical distribution of cross-holdings by bidder shareholders in the potential targets. Comparing these figures to those in Panel A of Table 3, it is

\footnotetext{
${ }^{11}$ Our main inferences remain unchanged if we impose different size matching criteria.
} 
clear that the cross-holdings by bidder shareholders in the actual targets are larger than in the potential targets (except where the cross-holdings are zero in both samples). Tests of differences in means and medians show that the cross-holdings by bidder shareholders in the chosen targets are significantly different from those in the control sample.

An alternative explanation for the difference in cross-holdings are unobservables, that is, institutions may invest in firms that are similar along some dimension that we do not observe, and that same similarity may make those firms more likely to merge. While this explanation is plausible for within-industry acquisitions, it is less likely to apply to diversifying acquisitions. It would have to be the case that institutions invest in firms across different industries based on some unobservable dimension that also makes these firms more likely to merge with each other. We check whether the difference in cross-holdings for actual versus potential targets holds for both diversifying and non-diversifying mergers, and indeed it does. We conclude that crossholdings by bidder shareholders are an important consideration in bidder management's choice of targets.

In untabulated results, we also examine the time-series of cross-holdings in the four quarters before a bid announcement. We find no evidence that cross-holdings in either party increase in the quarters leading-up to the bid. Thus, we find no evidence that institutions can predict bids or that they systematically increase their holdings in potential merger partners to trigger (or in anticipation of) a possible deal. Finally, we also confirm that the cross-holdings do not change significantly during the announcement quarter. If anything, we find that bidder shareholders with low cross-holdings tend to sell their stakes in the target, while bidder shareholders with high cross-holdings maintain their positions after the bid announcement. 


\section{E. The effect of cross-holdings on synergies}

Under the null hypothesis that cross-holdings matter in mergers, we conjecture that bidders select targets by trading off cross-holdings with synergies, and hence that synergies are on average lower for bids with higher bidder shareholder cross-holdings. Empirically, it is a challenge to measure synergies ex ante, suggesting that we could test our second testable implication by comparing the operating performance of firms with different cross-holdings $e x$ post. If the conjectured selection effect is true, then mergers associated with higher bidder crossholdings will have lower post-merger operating improvements-our proxy for costreduction/efficiency-based synergies - than those associated with low cross-holdings. . To focus on deals which are important to the bidding firm and its shareholders, we require that the target's size is at least five percent of the size of the bidder for these regressions. ${ }^{12}$

Table 7 presents the test results. The dependent variables are industry-adjusted returns on assets from one-year up to three-years after the merger. The key explanatory variables are the bidder's top- $20 \%$ and median cross-holdings. Given the difficulty of working with post-merger operating performance, the results are surprisingly strong. There is a significant negative relation between bidder shareholders' top-20\% cross-holdings and post-merger operating performance. The estimated effect grows with the time horizon and is significant for two- and three-year average post-merger ROAs. At the three-year horizon, a two standard deviation change in top$20 \%$ cross-holdings lowers the industry-adjusted ROA by 1.8 percent per year. These results support our conjecture that bidder management trades-off synergies and cross-holdings in target selection.

\section{III.F. The effect of cross-holdings on merger outcomes}

We next turn to the deal itself, examining the bidder and target abnormal announcement period returns, bid premiums, and the likelihood of deal completion as per our third testable

\footnotetext{
${ }^{12}$ All results are qualitatively unchanged when we include deals with smaller targets in the regressions.
} 
implication. The prior literature has found toeholds to be associated with higher returns to the bidder, lower bid premiums, and a higher probability of takeover success, and to have an ambiguous effect on target shareholder returns. ${ }^{13}$ We predicted that cross-holdings have a negative effect on bidder announcement returns, and we predicted an ambiguous effect on premiums and deal completion. Panels A to D of Table 8 summarize our test results. The key explanatory variables are once more the bidder's and target's median and top- $20 \%$ crossholdings, while other control variables are based on the prior literature.

Throughout, we find no effect of cross-holdings held by bidder shareholders on either announcement period returns, bid premiums, or the likelihood of deal completion. This result is robust in a wide variety of specifications; in untabulated regressions we have used cross-holdings calculated for alternative percentiles of the bidder's equity, we have experimented with dummy variables identifying bidders with extraordinarily high cross-holdings, and we have re-estimated our regressions for various subsets of the full sample chosen on the basis of deal size. ${ }^{14}$ Further, we have examined whether an effect becomes apparent only after 1992, when the SEC rules governing shareholder communication changed (SEC (1992)). We find no difference following the rule change. Focusing on the cross-holdings of bidder blockholders, either individually or as a group, shows similarly no effect of cross-holdings on any of the outcome variables.

Given that bidder managers are taking cross-holdings into account in target selection, they are clearly aware of the cross-holdings, and it seems unlikely that they start ignoring them subsequently. Rather, the results in Tables 7 and 8 are most consistent with our conjecture that bidders select targets by trading off cross-holdings with synergies. Since we are unable to perfectly control for synergies in Table 8 , we only observe the net effect of cross-holdings on

\footnotetext{
${ }^{13}$ On toeholds and bidder returns see Betton and Eckbo (2000), on toeholds and bid premiums see Walkling and Edmister (1985) and Betton and Eckbo (2000), on toeholds and the probability of takeover success see Walkling (1985), Jennings and Mazzeo (1993), and Betton and Eckbo (2000), and on toeholds and target shareholder returns see Eckbo and Langohr (1989), Jarrell and Poulsen (1989), Franks and Harris (1989), Stulz, Walkling, and Song (1990), and Betton and Eckbo (2000).

${ }^{14}$ We have also repeated the analysis after removing all institutional investors whose investment strategy appears to be that of an indexer. These "quasi-indexers" are identified following the approach in Bushee (1998). The inferences are unchanged.
} 
target selection and on bid aggressiveness. Hence chosen targets with high cross-holdings are likely to have lower synergies than targets with low cross-holdings, and the data may show, for example, that targets with high cross-holdings garner no higher premiums than those without. What this sample selection mechanism cannot explain are the insignificant bidder announcement returns. Because the benefits of more aggressive bidding accrue only to bidder shareholders with cross-holdings and not to the bidding firm itself, we had predicted a negative effect of crossholdings on bidder announcement returns.

We do find some evidence in Panels A to $\mathrm{C}$ that higher cross-holdings held by target shareholders in the bidder are associated with higher bidder announcement returns, lower target announcement returns, and lower bid premiums. This may suggest that large cross-holdings by target shareholders in the bidder weaken the target's takeover defenses and lead to a less expensive acquisition for the bidder. The estimated coefficients on other control variables are in keeping with expectations.

\section{III.G. The relationship between cross-holdings and governance}

The above results are broadly consistent with the conjecture that managers opportunistically take advantage of shareholder cross-holdings to reduce shareholder resistance to empire-building acquisitions. This interpretation also predicts higher cross-holdings for firms selected as targets, consistent with the results of Section III.D. However, we would expect this type of managerial behavior to be most prevalent in poorly governed firms. Thus, as per our final testable implication, we predict that higher bidder shareholder cross-holdings in chosen targets are associated with bidders that have the worst governance.

As our proxy for the quality of corporate governance, we use the Gompers, Ishii, and Metrick (2003) G-index, which is an aggregate measure of the level of shareholder rights in each

firm. We also include a modification to the G-index, the entrenchment- or E-index, in our analysis. Bebchuk, Cohen, and Ferrell (2006) develop the E-index by showing that only the six 
most economically motivated of the 24 provisions in the G-index are significantly associated with firm value.

Table 9 presents the correlation matrix between our measures of corporate governance and our measures of cross-holdings. For comparison, we also include total institutional ownership in the bidder and the target. Higher levels of the governance indexes indicate worse governance. Contrary to our fourth testable implication, we find a significant negative correlation between cross-holdings and the E-index, suggesting that managers in poorly governed firms are not more likely to pursue targets in which bidder shareholders have large cross-holdings. The correlations between the G-index and the cross-holdings measures are negative but insignificant. There is no pattern in the correlations between the governance indexes and total institutional ownership. The G-index is moderately positively correlated with the bidder's institutional ownership, while the E-index has a slightly higher but still moderate negative correlation with the target's institutional ownership. One interpretation of the latter finding is that poorly governed firms avoid targeting firms with a lot of institutional monitoring, perhaps to avoid inheriting those institutions in a stock-swap. We conclude that our evidence does not support the alternative explanation that managers use cross-holdings to reduce resistance to empire-building acquisitions.

\section{Summary and Conclusion}

This paper identifies and measures conflicts of interests among shareholders caused by differences in their portfolio compositions, and examines their effects in the case of corporate acquisitions. Diversified shareholders prefer corporate policies which maximize their portfolio values to policies which narrowly maximize the value of individual firms, and shareholders with different portfolios disagree about which actions firms should pursue. While the problem of shareholder heterogeneity examined here is general, the large premiums paid in acquisitions make it acute in this setting. 
We show how to correctly measure the shareholder preferences created by crossholdings, and we document their size and effects in takeover data from 1984 to 2002 . We find that the average acquirer's median institutional shareholder has a cross-holding of 5.3 percent in the target; the average top- $10 \%$ cross-holding is above 74 percent; and in five percent of the acquisitions even the median institution has a cross-holding of 40 percent or more. The average return improvement experienced by the median institutional shareholder is 0.2 percent, offsetting about 17 percent of the average bidder announcement return of -1.2 percent. At the same time, many institutional shareholders of the bidder have no cross-holdings in the target at all, implying substantial disagreements over the objective function of the bidder.

We test the null hypothesis that cross-holdings by bidder shareholders matter in mergers, and find evidence that bidders consider their shareholders' cross-holding when picking targets. Further, the operating performance of the merged firm is worse for bids associated with higher bidder shareholder cross-holdings. We find no observable effect of cross-holdings on the bidding strategies used by acquirers. Finally, if anything, the target selection result appears driven by better governed firms rather than poorly governed firms.

Our results are most consistent with bidder managers selecting targets along the dimensions of both synergies and cross-holdings, such that chosen targets with high crossholdings by bidder shareholders will tend to have lower synergies. With insufficient controls for synergies, aggressive bidding strategies for high cross-holding (and lower synergy) targets appear similar to normal bidding strategies for low cross-holding (and higher synergy) targets. Thus, the direct effect of cross-holdings on acquisition strategy and the indirect effect on synergy through target selection may effectively cancel each other out and lead to the observed noneffect. This stands in contrast to effects found in the extant literature for toeholds held directly by the bidder. However, in the case of direct toeholds, bidder management identifies a high synergy target and endogenously chooses to establish a toehold. In the case of cross-holdings, bidder management must take their shareholders' cross-holdings as given. 


\section{References}

Bebchuk, Lucian A., Alma Cohen, and Allen Ferrell, 2006, What Matters in Corporate Governance? Harvard Law School working paper.

Betton, Sandra, and B. Espen Eckbo, 2000, Toeholds, Bid-Jumps, and Expected Payoffs in Takeovers, Review of Financial Studies 13, 841-882

Bradley, Michael, Anand Desai, and E. Han Kim, 1988, Synergistic Gains from Corporate Acquisitions and Their Division Between the Stockholders of Target and Acquiring Firms, Journal of Financial Economics 21, 3-40.

Burkart, Mike, 1995, Initial Shareholdings and Overbidding in Takeover Contests, Journal of Finance 50, 1491-1515.

Bushee, Brian J., 1998, The Influence of Institutional Investors on Myopic R\&D Investment Behavior, Accounting Review 73, 305-333.

Carleton, Willard T., James M. Nelson, and Michael Weisbach, 1998, The Influence of Institutions on Corporate Governance through Private Negotiations: Evidence from TIAA-CREF, Journal of Finance 53, 1335-1362.

Chowdhry, Bhagwan, and Narasimhan Jegadeesh, 1994, Pre-Tender Offer Share Acquisition Strategy in Takeovers, Journal of Financial and Quantitative Analysis 29, 117-129.

Coase, Ronald H., 1960, The Problem of Social Cost, Journal of Law and Economics 3, 1-44

Drèze, Jaques H., 1974, Investment under Private Ownership: Optimality, Equilibrium and Stability, in: Allocation under Uncertainty: Equilibrium and Optimality, Jaques H. Drèze (ed.), John Wiley and Sons, New York.

Eckbo, B. Espen, and Herwig Langohr, 1989, Information Disclosure, Means of Payment, and Takeover Premiums: Public and Private Tender Offers in France, Journal of Financial Economics 24, 363-403.

Eckbo, B. Espen, and Savita Verma, 1994, Managerial Share Ownership, Voting Power, and Cash Dividend Policy, Journal of Corporate Finance 1, 33-62.

Fama, Eugene, and Kenneth French, 1997, Industry Costs of Capital, Journal of Financial Economics 43, 153-193.

Fishman, Michael J., 1988, A Theory of Preemptive Takeover Bidding, Rand Journal of Economics 19, 88-101.

Franks, Julian R., and Robert S. Harris, 1989, Shareholder Wealth Effects of Corporate Takeovers: The UK Experience 1955-85, Journal of Financial Economics 23, 225-49. 
Gompers, Paul A., Joy Ishii, and Andrew Metrick, 2003, Corporate Governance and Equity Prices, Quarterly Journal of Economics 118, 107-155.

Grossman, Sanford J., and Oliver D. Hart, 1980, Takeovers, the Free-Rider Problem and the Theory of the Corporation, Bell Journal of Economics 11, 42-64.

Hansen, Robert G., and John R. Lott Jr., 1996, Externalities and Corporate Objectives in a World with Diversified Shareholder/Consumers, Journal of Financial and Quantitative Analysis 31, 43-68.

Hart, Oliver, 1979, On Shareholder Unanimity in Large Stock Market Economies, Econometrica 47, 1057-1083.

Hirshleifer, David, and Sheridan Titman, 1990, Share Tendering Strategies and the Success of Hostile Takeover Bids, Journal of Political Economy 98, 295-324.

Jarrell, Gregg A., and Annette B. Poulsen, 1989, Stock Trading before the Announcement of Tender Offers: Insider Trading or Market Anticipation?, Journal of Law, Economics and Organizations 5, 225-248.

Jennings, Robert H., and Michael A. Mazzeo, 1993, Competing Bids. Target Management Resistance, and the Structure of Takeover Bids, Review of Financial Studies 6, 883-909.

Kraus, Alan, and Amir Rubin, 2007, Reducing Managers' Incentives to Cannibalize: Managerial Stock Options When Shareholders Are Diversified, University of British Columbia and Simon Fraser University working paper.

Matvos, Gregor, and Michael Ostrovsky, 2006, Cross-Ownership, Returns, and Voting in Mergers, Harvard University and Stanford University working paper.

Murphy, Kevin J., 1999, Executive Compensation, in: Handbook of Labor Economics, Orley Ashenfelter and David Card (eds.), Vol. 3b, Elsevier Science North Holland, 2485-2563.

Rice, Edward M., 2006, What Stock Price Changes Mean When Events Affect Shareholders Differently, University of Washington working paper.

Rubin, Amir, 2006, Diversification and Corporate Decisions, Corporate Ownership and Control 3, 209-212.

Securities and Exchange Commission, 1992, "Regulation of Communication Among Shareholders," Securities Exchange Act of 1934 Release No. 31,326, 57 Fed. Reg. 48,276, Oct. 16.

Shleifer, Andrei, and Robert W. Vishny, 1986, Large Shareholders and Corporate Control, Journal of Political Economy 94, 461-488.

Singh, Rajdeep, 1998, Takeover Bidding with Toeholds: The Case of the Owner's Curse, Review of Financial Studies 11, 679-704. 
Smith, Michael P., 1996, Shareholder Activism by Institutional Investors: Evidence from CalPERS, Journal of Finance 51, 227-252.

Stulz, René M., Ralph A. Walkling, and Moon H. Song, 1990, The Distribution of Target Ownership and the Division of Gains in Successful Takeovers, Journal of Finance 45, 817-834.

Walkling, Ralph A., and Robert O. Edmister, 1985, Determinants of Tender Offer Premiums, Financial Analysts Journal 41, 27-37.

Walkling, Ralph A., 1985, Predicting Tender Offer Success: A Logistic Analysis, Journal of Financial and Quantitative Analysis 20, 461-478. 


\section{Figure 1}

\section{Bidder Institutional Investors' Cross-holdings in the Target}

This figure illustrates how the bidder institutional shareholders' cross-holdings in the target are measured. We first rank all bidder institutional investors by their cross-holdings in the target, defined as their percentage ownership of the target divided by their percentage ownership of the bidder. Using this ranking, we then calculate the marginal cross-holdings associated with the top 1, 5, 10, 20, and 50 percent of institutional shareholdings. In the example illustrated below, one percent of the bidder's institutional shareholdings are owned by shareholders with crossholdings of at least $116 \%$, and hence the top-1\% cross-holding is set to 116 percent. Twenty percent of the bidder's institutional shareholdings are by shareholders with cross-holdings of at least 45 percent, and hence the top-20\% cross-holding is 45 percent. Finally, the median institutional shareholder has a cross-holding of 24 percent in the target, which we call the median cross-holding for short.

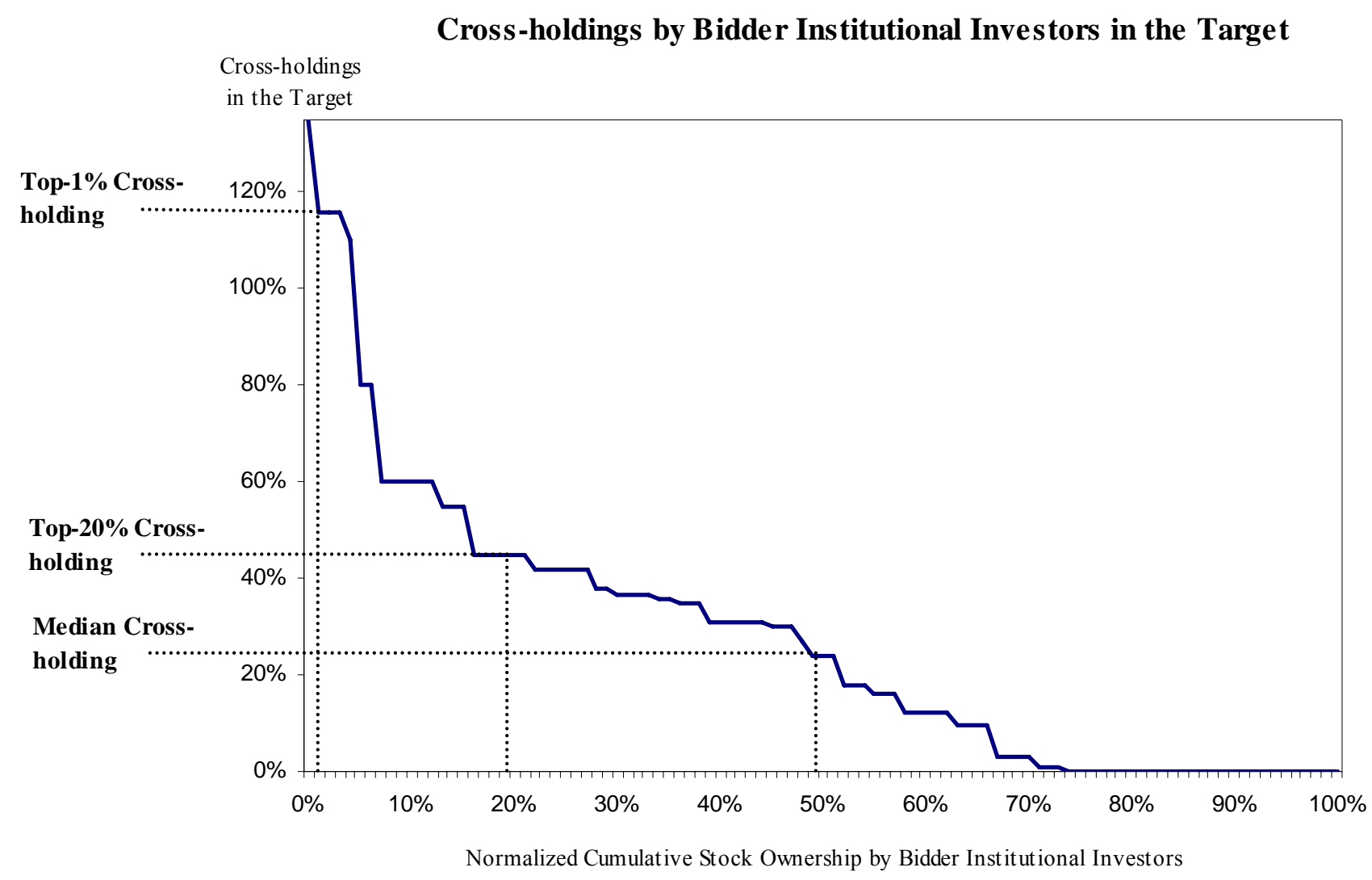


Table 1

Summary Statistics on Merger Bids, Bidders, and Targets, 1984-2002

The sample consists of 2,815 acquisitions announced during the period January 1, 1984, to December 31 , 2002. The bidders and targets are listed in the SDC's Mergers and Acquisitions database and have institutional holding data in the CDA/Spectrum database. We keep an acquisition if the bidder owns less than 50 percent of the target prior to the bid and is seeking to own greater than 50 percent of the target. For completed deals, we require that the bidder owns more than 90 percent of the target after the deal completion. All dollar amounts are in 2002 millions of dollars, all percentages are in real numbers.

\section{Panel A: Deal Characteristics}

Complete, All Cash, All Stock, Competing, and Diversifying are dummy variables that take the value of one for completed acquisitions, if only cash is used to pay for the acquisition, if only equity is used, if there are multiple bids for the same target within one year, if the bidder and target are from two different industries, respectively, and zero otherwise. Relative Size is the transaction value divided by the market value of bidder assets at the end of the fiscal year prior to the bid announcement. Toehold measures the percentage of the target's shares held by the bidder prior to the bid announcement. Premium is the ratio of the final offer price to the target's trading price four weeks prior to the original announcement date minus one.

\begin{tabular}{lrrrrrr}
\hline \hline & $\mathrm{N}$ & Mean & StdDev & Percentile & Median & $\begin{array}{r}5^{\text {th }} \\
\text { Percentile }\end{array}$ \\
\hline & & & & & & \\
Complete & 2815 & 0.753 & 0.431 & 0.000 & 1.000 & 1.000 \\
All Cash & 2815 & 0.256 & 0.437 & 0.000 & 0.000 & 1.000 \\
All Stock & 2815 & 0.415 & 0.493 & 0.000 & 0.000 & 1.000 \\
Competing & 2815 & 0.134 & 0.341 & 0.000 & 0.000 & 1.000 \\
Diversifying & 2815 & 0.477 & 0.500 & 0.000 & 0.000 & 1.000 \\
Relative Size & 2600 & 0.298 & 0.653 & 0.004 & 0.101 & 1.081 \\
Toehold & 2815 & 0.006 & 0.043 & 0.000 & 0.000 & 0.000 \\
Premium & 2508 & 0.447 & 0.524 & -0.057 & 0.365 & 1.160 \\
\hline
\end{tabular}

\section{Panel B: Announcement Period Returns, Synergy, and Total Returns}

The abnormal announcement period returns (CAR3) are over days $(-1,1)$, where day 0 is the date of the initial bid announcement by the acquiring firm. Daily abnormal stock returns are computed using the market model and the value-weighted CRSP index. The estimation window is days $(-200,-60)$ prior to the acquisition announcement date. Following Bradley, Desai, and Kim (1988), the percentage synergy gain is defined as the cumulative abnormal return over the $(-1,+1)$ event window for a value-weighted portfolio of the target and bidder. The weights for the bidder and the target are based on the market value of equity two days prior to the bid announcement. The target weight adjusts for the percentage of target shares held by the acquirer prior to the announcement of the deal, with the adjustment set to zero for missing toehold values. The dollar value synergistic gain over the same event window ( -1 , $+1)$ is defined as the percentage synergy gain times the sum of the market values of equity for the bidder and the target in million dollars, again adjusted for the percentage of target shares held by the acquirer prior to the announcement of the deal.

\begin{tabular}{lrrrrrr}
\hline \hline & & & & $5^{\text {th }}$ & $95^{\text {th }}$ \\
& N & Mean & StdDev & Percentile & Median & Percentile \\
\hline & & & & & & \\
Bidder CAR3 & 2815 & -0.012 & 0.085 & -0.129 & -0.009 & 0.092 \\
Target CAR3 & 2815 & 0.196 & 0.248 & -0.072 & 0.145 & 0.628 \\
Synergy (\$) & 2815 & 46.813 & 1451.867 & -624.124 & 8.261 & 916.737 \\
Synergy (\%) & 2815 & 0.020 & 0.084 & -0.082 & 0.012 & 0.143 \\
\hline
\end{tabular}


Panel C: Bidder Characteristics

\begin{tabular}{lrrrrrr}
\hline \hline & & & & $5^{\text {th }}$ & & $95^{\text {th }}$ \\
& N & Mean & StdDev & Percentile & Median & Percentile \\
\hline Market Capitalization & 2815 & 8901 & 29487 & 50 & 1512 & 35670 \\
Market Value Total Assets & 2815 & 20148 & 57655 & 87 & 3390 & 94310 \\
Book Value Total Assets & 2815 & 13710 & 43250 & 56 & 1977 & 60871 \\
Sales & 2815 & 5010 & 11555 & 33 & 1087 & 23364 \\
Market Leverage & 2808 & 0.162 & 0.140 & 0.000 & 0.134 & 0.433 \\
Book Leverage & 2808 & 0.227 & 0.176 & 0.000 & 0.204 & 0.543 \\
Market-to-Book Ratio & 2815 & 2.068 & 2.705 & 0.974 & 1.398 & 4.991 \\
Sales Growth & 2815 & 0.345 & 1.155 & -0.149 & 0.136 & 1.200 \\
Return on Assets & 2815 & 0.151 & 0.177 & -0.019 & 0.143 & 0.415 \\
Prior Year Stock Return & 2815 & 0.316 & 0.802 & -0.401 & 0.193 & 1.264 \\
Prior Year Mkt-Adj Return & 2815 & 0.162 & 0.786 & -0.525 & 0.038 & 1.091 \\
\hline
\end{tabular}

Panel D: Target Characteristics

\begin{tabular}{|c|c|c|c|c|c|c|}
\hline & $\mathrm{N}$ & Mean & StdDev & $\begin{array}{r}5^{\text {th }} \\
\text { Percentile } \\
\end{array}$ & Median & $\begin{array}{r}95^{\text {th }} \\
\text { Percentile } \\
\end{array}$ \\
\hline Market Capitalization & 2815 & 1213 & 4905 & 13 & 154 & 5097 \\
\hline Market Value Total Assets & 2815 & 4208 & 22022 & 25 & 411 & 13334 \\
\hline Book Value Total Assets & 2815 & 3495 & 20498 & 17 & 292 & 10803 \\
\hline Sales & 2815 & 1292 & 4634 & 12 & 177 & 5823 \\
\hline Market Leverage & 2810 & 0.176 & 0.167 & 0.000 & 0.137 & 0.503 \\
\hline Book Leverage & 2810 & 0.223 & 0.204 & 0.000 & 0.185 & 0.606 \\
\hline Market-to-Book Ratio & 2815 & 1.672 & 1.535 & 0.856 & 1.207 & 3.713 \\
\hline Sales Growth & 2815 & 0.242 & 0.940 & -0.221 & 0.103 & 0.952 \\
\hline Return on Assets & 2815 & 0.094 & 0.195 & -0.178 & 0.105 & 0.333 \\
\hline Prior Year Stock Return & 2815 & 0.173 & 0.816 & -0.641 & 0.080 & 1.072 \\
\hline Prior Year Mkt-Adj Return & 2815 & 0.018 & 0.805 & -0.743 & -0.077 & 0.902 \\
\hline
\end{tabular}


Table 2

Summary Statistics on Institutional Ownership in Bidders and Targets, 1984-2002

The sample consists of 2,815 acquisitions announced during the period January 1, 1984, to December 31, 2002. The bidders and targets are listed in the SDC's Mergers and Acquisitions database and have institutional holding data in the CDA/Spectrum database. We keep an acquisition if the bidder owns less than 50 percent of the target prior to the bid and is seeking to own greater than 50 percent of the target. For completed deals, we require that the bidder owns more than 90 percent of the target after the deal completion. All dollar amounts are in 2002 millions of dollars, all percentages are in real numbers.

\section{Panel A: Institutional Ownership in Bidders}

Total Institutional Ownership is the fraction of a bidder's stock that is owned by institutional investors. Total Blockholder Ownership is the fraction of a bidder's stock that is owned by block institutional investors with share ownership no less than five percent. Bidder Institutions Owning Shares in Target gives the total shareholdings in the bidder by institutions who also own shares in the target. Fraction of Bidder Institutional Ownership Owned by Institutions with Shares in Target gives the percentage of the bidder's institutional ownership that is held by institutions who also own shares in the target.

\begin{tabular}{|c|c|c|c|c|c|c|}
\hline & $\mathrm{N}$ & Mean & StdDev & $\begin{array}{r}5^{\text {th }} \\
\text { Percentile }\end{array}$ & Median & $\begin{array}{r}95^{\text {th }} \\
\text { Percentile } \\
\end{array}$ \\
\hline Total Institutional Ownership & 2815 & 0.464 & 0.232 & 0.064 & 0.485 & 0.827 \\
\hline Total Blockholder Ownership & 1692 & 0.153 & 0.101 & 0.053 & 0.125 & 0.357 \\
\hline $\begin{array}{l}\text { Bidder Institutions Owning Shares in Target } \\
\text { Fraction of Bidder Institutional Ownership }\end{array}$ & 2815 & 0.144 & 0.142 & 0.002 & 0.091 & 0.442 \\
\hline Owned by Institutions with Shares in Target & 2815 & 0.309 & 0.242 & 0.014 & 0.251 & 0.790 \\
\hline
\end{tabular}

\section{Panel B: Institutional Ownership in Targets}

Total Institutional Ownership is the fraction of a target's stock that is owned by institutional investors. Total Blockholder Ownership is the fraction of a target's stock that is owned by block institutional investors with share ownership no less than five percent. Target Institutions Owning Shares in Bidder gives the total shareholdings in the target by institutions who also own shares in the bidder. Fraction of Target Institutional Ownership Owned by Institutions with Shares in Bidder gives the percentage of the target's institutional ownership that is held by institutions who also own shares in the bidder.

\begin{tabular}{lcccccc}
\hline \hline & & & & $5^{\text {th }}$ & & $95^{\text {th }}$ \\
& $\mathrm{N}$ & Mean & StdDev & Percentile & Median & Percentile \\
\hline & & & & & & \\
Total Institutional Ownership & 2815 & 0.324 & 0.233 & 0.016 & 0.280 & 0.759 \\
Total Blockholder Ownership & 1764 & 0.160 & 0.108 & 0.054 & 0.133 & 0.376 \\
Target Institutions Owning Shares in Bidder & 2815 & 0.179 & 0.172 & 0.002 & 0.123 & 0.543 \\
Fraction of Target Institutional Ownership & & & & & & \\
Owned by Institutions with Shares in Bidder & 2815 & 0.535 & 0.282 & 0.044 & 0.551 & 0.981 \\
\hline
\end{tabular}


Table 3

Summary Statistics on Cross-holdings By Shareholders in Bidders and Targets

The sample consists of 2,815 acquisitions announced during the period January 1, 1984, to December 31, 2002. The bidders and targets are listed in the SDC's Mergers and Acquisitions database and have institutional holding data in the CDA/Spectrum database. We keep an acquisition if the bidder owns less than 50 percent of the target prior to the bid and is seeking to own greater than 50 percent of the target. For completed deals, we require that the bidder owns more than 90 percent of the target after the deal completion. All dollar amounts are in 2002 millions of dollars, all percentages are in real numbers.

\section{Panel A: The Cumulative Distribution of Cross-holdings by Bidder Shareholders}

Cross-holdings are defined as the ratio of the shareholder's percentage ownership in the target divided by her percentage ownership in the bidder. We order all institutional investors by their cross-holdings, and then report the (marginal) cross-holding for the top 1, 5, 10, 20, and 50 percent of institutional shareholdings (labeled as the top$1 \%$, top-5\%, top-10\%, top-20\%, and median cross-holdings, respectively). We require that at least 20 percent of the bidder's equity is owned by institutions for this analysis. In addition to the analysis for institutional shareholders, we calculate cross-holdings for all the bidder's shareholders under the conservative assumption that all non-institutional investors have zero cross-holdings. Here the percentiles are with respect to all shareholders, and we do not impose the requirement that institutional investors own at least 20 percent of the bidder. Bidder Institutional Holdings with Cross-holding $\geq 1$ gives the total shareholdings in the bidder by institutions whose cross-holdings are larger than one. Fraction of Bidder Institutional Holdings with Cross-holding $\geq 1$ gives the percentage of the bidder's institutional ownership that is owned by institutions with cross-holdings larger than one. We report cross-holdings for percentiles of (the actually observed) institutional investors in Part I and for percentiles of all shareholders in Part II of Panel A.

\begin{tabular}{|c|c|c|c|c|c|c|c|c|}
\hline & $\mathrm{N}$ & Mean & StdDev & Median & $\begin{array}{r}75^{\text {th }} \\
\text { Percentile }\end{array}$ & $\begin{array}{r}90^{\text {th }} \\
\text { Percentile } \\
\end{array}$ & $\begin{array}{r}95^{\text {th }} \\
\text { Percentile }\end{array}$ & $\begin{array}{r}99^{\text {th }} \\
\text { Percentile }\end{array}$ \\
\hline \multicolumn{9}{|c|}{ I: Cross-holding by All Institutional Investors from Bidders with Total Institutional Ownership $\geq 0.2$} \\
\hline Top-1\% Cross-holding & 2356 & 4.631 & 4.895 & 3.281 & 6.223 & 10.216 & 13.309 & 22.759 \\
\hline Top-5\% Cross-holding & 2356 & 1.396 & 1.281 & 1.154 & 1.905 & 2.976 & 3.740 & 5.683 \\
\hline Top-10\% Cross-holding & 2356 & 0.747 & 0.733 & 0.619 & 1.139 & 1.720 & 2.125 & 3.065 \\
\hline Top- $20 \%$ Cross-holding & 2356 & 0.344 & 0.451 & 0.100 & 0.616 & 1.027 & 1.224 & 1.639 \\
\hline Median Cross-holding & 2356 & 0.053 & 0.162 & 0.000 & 0.000 & 0.162 & 0.397 & 0.866 \\
\hline \multicolumn{9}{|c|}{ II: Cross-holding by All Bidder Shareholders } \\
\hline Top-1\% Cross-holding & 2815 & 2.544 & 2.567 & 1.764 & 3.564 & 6.023 & 7.619 & 11.209 \\
\hline Top-5\% Cross-holding & 2815 & 0.661 & 0.752 & 0.431 & 1.102 & 1.706 & 2.168 & 3.078 \\
\hline Top-10\% Cross-holding & 2815 & 0.295 & 0.445 & 0.000 & 0.533 & 1.009 & 1.232 & 1.689 \\
\hline Top- $20 \%$ Cross-holding & 2815 & 0.099 & 0.236 & 0.000 & 0.013 & 0.402 & 0.718 & 1.019 \\
\hline Median Cross-holding & 2815 & 0.003 & 0.029 & 0.000 & 0.000 & 0.000 & 0.000 & 0.079 \\
\hline \multicolumn{9}{|l|}{ Bidder Institutional Holdings with } \\
\hline Cross-holding $\geq 1$ & 2815 & 0.041 & 0.047 & 0.025 & 0.058 & 0.103 & 0.139 & 0.217 \\
\hline \multicolumn{9}{|l|}{ Fraction of Bidder Institutional } \\
\hline Holdings with Cross-holding $\geq 1$ & 2815 & 0.101 & 0.127 & 0.063 & 0.135 & 0.235 & 0.326 & 0.619 \\
\hline
\end{tabular}




\section{Panel B: The Cumulative Distribution of Cross-holdings by Target Shareholders}

Cross-holdings are defined as the ratio of the shareholder's percentage ownership in the bidder divided by her percentage ownership in the target. We order all institutional investors by their cross-holdings, and then report the (marginal) cross-holding for the top 1, 5, 10, 20, and 50 percent of institutional shareholdings (labeled as the top$1 \%$, top-5\%, top-10\%, top-20\%, and median cross-holdings, respectively). We require that at least 20 percent of the target's equity is owned by institutions for this analysis. In addition to the analysis for institutional shareholders, we calculate cross-holdings for all the target's shareholders under the conservative assumption that all non-institutional investors have zero cross-holdings. Here the percentiles are with respect to all shareholders, and we do not impose the requirement that institutional investors own at least 20 percent of the target. Target Institutional Holdings with Cross-holding $\geq 1$ gives the total shareholdings in the target by institutions whose cross-holdings are larger than one. Fraction of Target Institutional Holdings with Cross-holding $\geq 1$ gives the percentage of the target's institutional ownership that is owned by institutions with cross-holdings larger than one. We report cross-holdings for percentiles of (the actually observed) institutional investors in Part I and for percentiles of all shareholders in Part II of Panel B.

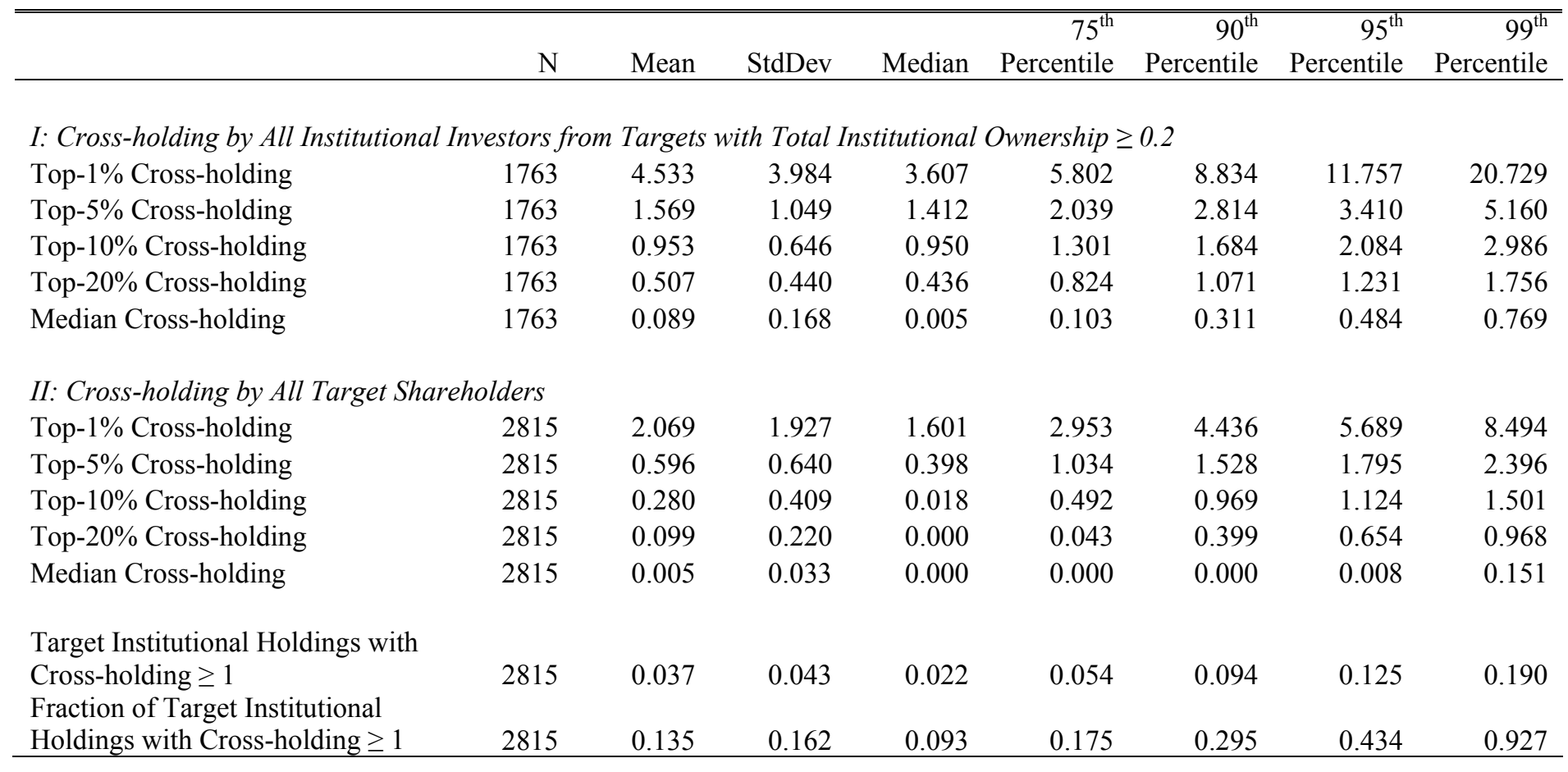


Table 4

Summary Statistics on Cross-holdings By Block Institutional Investors in Bidders and Targets

The sample consists of 2,815 acquisitions announced during the period January 1, 1984, to December 31, 2002. The bidders and targets are listed in the SDC's Mergers and Acquisitions database and have institutional holding data in the CDA/Spectrum database. We keep an acquisition if the bidder owns less than 50 percent of the target prior to the bid and is seeking to own greater than 50 percent of the target. For completed deals, we require that the bidder owns more than 90 percent of the target after the deal completion. All dollar amounts are in 2002 millions of dollars, all percentages are in real numbers.

\section{Panel A: The Cumulative Distribution of Cross-holdings by Bidder Blockholders}

Cross-holdings are defined as the ratio of the shareholder's percentage ownership in the target divided by her percentage ownership in the bidder. This table focuses on large shareholders, defined as blockholders with ownership no less than five percent. The sample is restricted to deals with at least one blockholder in the bidder. We order the blockholders by their cross-holdings, and then report the (marginal) cross-holding for the top 5, 10, 20, 50, 75, and 100 percent of blockholdings (labeled as the top-5\%, top-10\%, top-20\%, median, top-75\%, and all crossholdings, respectively). We compute two cross-holding measures: for all blockholders, and for all blockholders combined assuming they exchange side payments and act as a group (combined cross-holding). We present the empirical distribution of the two measures in Parts I and II of Panel A, respectively.

\begin{tabular}{|c|c|c|c|c|c|c|c|c|}
\hline & & & & & $75^{\text {th }}$ & $90^{\text {th }}$ & $95^{\text {th }}$ & $99^{\text {th }}$ \\
\hline & $\mathrm{N}$ & Mean & StdDev & Median & Percentile & Percentile & Percentile & Percentile \\
\hline \multicolumn{9}{|c|}{ I: Cross-holding by All Bidder Blockholders } \\
\hline Top-5\% Cross-holding & 1692 & 0.199 & 0.418 & 0.000 & 0.154 & 0.799 & 1.135 & 1.936 \\
\hline Top-10\% Cross-holding & 1692 & 0.199 & 0.418 & 0.000 & 0.154 & 0.799 & 1.135 & 1.936 \\
\hline Top- $20 \%$ Cross-holding & 1692 & 0.181 & 0.395 & 0.000 & 0.125 & 0.711 & 1.060 & 1.834 \\
\hline Median Cross-holding & 1692 & 0.109 & 0.300 & 0.000 & 0.015 & 0.392 & 0.820 & 1.470 \\
\hline Top-75\% Cross-holding & 1692 & 0.071 & 0.245 & 0.000 & 0.000 & 0.156 & 0.512 & 1.385 \\
\hline All Cross-holding & 1692 & 0.069 & 0.243 & 0.000 & 0.000 & 0.149 & 0.497 & 1.385 \\
\hline \multicolumn{9}{|c|}{ II: Combined Cross-holding by All Bidder Blockholders } \\
\hline Combined Cross-holding & 1692 & 0.121 & 0.279 & 0.000 & 0.084 & 0.457 & 0.689 & 1.385 \\
\hline
\end{tabular}




\section{Panel B: The Cumulative Distribution of Cross-holdings by Target Blockholders}

Cross-holdings are defined as the ratio of the shareholder's percentage ownership in the bidder divided by her percentage ownership in the target. This table focuses on large shareholders, defined as blockholders with ownership no less than five percent. The sample is restricted to deals with at least one blockholder in the target. We order the blockholders by their cross-holdings, and then report the (marginal) cross-holding for the top 5, 10, 20, 50,75, and 100 percent of blockholdings (labeled as the top-5\%, top-10\%, top-20\%, median, top-75\%, and all cross-holdings, respectively). We compute two cross-holding measures: for all blockholders, and for all blockholders combined assuming they exchange side payments and act as a group (combined cross-holding). We present the empirical distribution of the two measures in Parts I and II of Panel B, respectively.

\begin{tabular}{|c|c|c|c|c|c|c|c|c|}
\hline & & & & & $75^{\text {th }}$ & $90^{\text {th }}$ & $95^{\text {th }}$ & $99^{\text {th }}$ \\
\hline & $\mathrm{N}$ & Mean & StdDev & Median & Percentile & Percentile & Percentile & Percentile \\
\hline \multicolumn{9}{|c|}{ I: Cross-holding by All Target Blockholders } \\
\hline Top-5\% Cross-holding & 1764 & 0.214 & 0.379 & 0.016 & 0.272 & 0.722 & 1.002 & 1.698 \\
\hline Top-10\% Cross-holding & 1764 & 0.213 & 0.377 & 0.016 & 0.270 & 0.721 & 1.000 & 1.675 \\
\hline Top- $20 \%$ Cross-holding & 1764 & 0.202 & 0.363 & 0.012 & 0.241 & 0.701 & 0.986 & 1.646 \\
\hline Median Cross-holding & 1764 & 0.114 & 0.269 & 0.000 & 0.078 & 0.377 & 0.701 & 1.348 \\
\hline Top-75\% Cross-holding & 1764 & 0.077 & 0.217 & 0.000 & 0.019 & 0.252 & 0.514 & 1.070 \\
\hline All Cross-holding & 1764 & 0.073 & 0.215 & 0.000 & 0.015 & 0.233 & 0.505 & 1.070 \\
\hline \multicolumn{9}{|c|}{ II: Combined Cross-holding by All Target Blockholders } \\
\hline Combined Cross-holding & 1764 & 0.132 & 0.251 & 0.010 & 0.149 & 0.433 & 0.699 & 1.136 \\
\hline
\end{tabular}




\section{Table 5}

\section{Return Improvement for Bidder Shareholders Around Merger Announcements}

The sample consists of 2,815 acquisitions announced during the period January 1, 1984, to December 31, 2002. The bidders and targets are listed in the SDC's Mergers and Acquisitions database and have institutional holding data in the CDA/Spectrum database. We keep an acquisition if the bidder owns less than 50 percent of the target prior to the bid and is seeking to own greater than 50 percent of the target. For completed deals, we require that the bidder owns more than 90 percent of the target after the deal completion. All dollar amounts are in 2002 millions of dollars, all percentages are in real numbers. The return improvement for each bidder institutional shareholder is computed as the difference between her total abnormal announcement return and the bidder abnormal announcement period return. The total abnormal announcement return for each bidder institutional shareholder is the ownership-weighted average abnormal return on her stakes in the bidder and the target and is defined in equation (3). The abnormal announcement period returns (CAR3) are over days $(-1,1)$, where day 0 is the date of the initial bid announcement by the acquiring firm. Daily abnormal stock returns are computed using the market model and the value-weighted CRSP index. The estimation window is days $(-200,-60)$ prior to the acquisition announcement date. We report the distribution of return improvement for different institutional investors based on their cross-holdings as defined in Table 3 Panel A.

\begin{tabular}{|c|c|c|c|c|c|c|c|c|}
\hline & $\mathrm{N}$ & Mean & StdDev & Median & $\begin{array}{r}75^{\text {th }} \\
\text { Percentile } \\
\end{array}$ & $\begin{array}{r}90^{\text {th }} \\
\text { Percentile }\end{array}$ & $\begin{array}{r}95^{\text {th }} \\
\text { Percentile } \\
\end{array}$ & $\begin{array}{r}99^{\text {th }} \\
\text { Percentile } \\
\end{array}$ \\
\hline \multicolumn{9}{|c|}{ I. Return Improvement by All Institutional Investors from Bidders with Total Institutional Ownership $\geq 0.2$} \\
\hline Top-1\% by Cross-holding & 2356 & 0.066 & 0.102 & 0.030 & 0.102 & 0.190 & 0.255 & 0.427 \\
\hline Top-5\% by Cross-holding & 2356 & 0.037 & 0.066 & 0.012 & 0.053 & 0.118 & 0.169 & 0.284 \\
\hline Top- $10 \%$ by Cross-holding & 2356 & 0.025 & 0.051 & 0.004 & 0.032 & 0.086 & 0.127 & 0.216 \\
\hline Top- $20 \%$ by Cross-holding & 2356 & 0.014 & 0.034 & 0.000 & 0.012 & 0.051 & 0.086 & 0.149 \\
\hline Median by Cross-holding & 2356 & 0.002 & 0.012 & 0.000 & 0.000 & 0.004 & 0.017 & 0.062 \\
\hline \multicolumn{9}{|c|}{ II. Return Improvement by All Bidder Shareholders } \\
\hline Top- $1 \%$ by Cross-holding & 2815 & 0.051 & 0.088 & 0.019 & 0.078 & 0.156 & 0.213 & 0.380 \\
\hline Top- $5 \%$ by Cross-holding & 2815 & 0.023 & 0.050 & 0.002 & 0.026 & 0.080 & 0.121 & 0.221 \\
\hline Top-10\% by Cross-holding & 2815 & 0.012 & 0.031 & 0.000 & 0.008 & 0.042 & 0.076 & 0.149 \\
\hline Top- $20 \%$ by Cross-holding & 2815 & 0.005 & 0.019 & 0.000 & 0.000 & 0.011 & 0.034 & 0.091 \\
\hline Median by Cross-holding & 2815 & 0.000 & 0.004 & 0.000 & 0.000 & 0.000 & 0.000 & 0.004 \\
\hline
\end{tabular}




\section{Table 6}

\section{The Effect of Cross-holdings on Target Selection}

Our control sample of potential target firms is obtained by first identifying all CRSP/Compustat firms that were neither targets nor bidders in our merger sample. This forms the base set of potential control firms. For each target in our sample, we select a control firm in the same Fama-French (1997) industry with the closest market capitalization to that of the sample firm (requiring that the difference does not exceed $25 \%$ of the sample firm market capitalization) at the fiscal year-end prior to the bid announcement, and with institutional shareholding data from the CDA. Matching is done with replacement and only one control firm is matched to each sample firm. We end up with 2,427 control firms for target firms in our sample. Panel A presents the summary statistics of our control sample. Panel B presents the cumulative distribution of cross-holdings by bidder shareholders in target control firms. The last two columns of each panel present the $\mathrm{p}$ values of tests for differences in means and medians, respectively, from the corresponding figures for the actual targets, presented in Tables 1 and 3.

\section{Panel A: Target Control Characteristics}

\begin{tabular}{|c|c|c|c|c|c|c|c|c|}
\hline & & & & $5^{\text {th }}$ & & $95^{\text {th }}$ & & Median \\
\hline & $\mathrm{N}$ & Mean & StdDev & Percentile & Median & Percentile & T-Test & Test \\
\hline Market Capitalization & 2427 & 935.203 & 3715.906 & 14.447 & 146.642 & 3970.715 & 1.000 & 1.000 \\
\hline Market Value Total Assets & 2427 & 3025.615 & 15324.166 & 26.635 & 361.859 & 9413.135 & 0.358 & 0.153 \\
\hline Book Value Total Assets & 2427 & 2492.444 & 14024.565 & 12.819 & 248.012 & 7678.903 & 0.315 & 0.009 \\
\hline Sales & 2427 & 983.157 & 4812.033 & 6.702 & 154.140 & 4065.943 & 0.528 & 0.010 \\
\hline Market Leverage & 2423 & 0.177 & 0.178 & 0.000 & 0.130 & 0.527 & 0.760 & 0.446 \\
\hline Book Leverage & 2423 & 0.231 & 0.238 & 0.000 & 0.185 & 0.641 & 0.113 & 0.602 \\
\hline Market-to-Book Ratio & 2427 & 1.940 & 2.383 & 0.881 & 1.277 & 5.117 & $<0.001$ & $<0.001$ \\
\hline Sales Growth & 2427 & 1.065 & 32.888 & -0.250 & 0.117 & 1.067 & 0.220 & 0.009 \\
\hline Return on Assets & 2427 & 0.089 & 0.242 & -0.264 & 0.112 & 0.366 & 0.653 & 0.242 \\
\hline Prior Year Stock Return & 2427 & 0.181 & 0.854 & -0.627 & 0.080 & 1.184 & 0.757 & 0.628 \\
\hline Prior Year Mkt-Adj Return & 2427 & 0.026 & 0.839 & -0.729 & -0.084 & 1.014 & 0.753 & 0.917 \\
\hline Total Institutional Ownership & 2427 & 0.322 & 0.231 & 0.018 & 0.277 & 0.758 & 0.474 & 0.487 \\
\hline
\end{tabular}


Panel B: The Cumulative Distribution of Cross-holdings by Bidder Shareholders in Target Control Firms

\begin{tabular}{|c|c|c|c|c|c|c|c|c|c|c|}
\hline & & & & & $75^{\text {th }}$ & $90^{\text {th }}$ & $95^{\text {th }}$ & $99^{\text {th }}$ & & Median \\
\hline & $\mathrm{N}$ & Mean & StdDev & Median & Percentile & Percentile & Percentile & Percentile & T-test & Test \\
\hline \multicolumn{11}{|c|}{ I: Cross-holding by All Institutional Investors from Bidders with Total Institutional Ownership $\geq 0.2$} \\
\hline Top-1\% Cross-holding & 2023 & 4.125 & 5.143 & 2.479 & 5.381 & 9.450 & 13.648 & 23.366 & 0.009 & $<0.001$ \\
\hline Top-5\% Cross-holding & 2023 & 1.166 & 1.281 & 0.888 & 1.601 & 2.626 & 3.546 & 6.213 & $<0.001$ & $<0.001$ \\
\hline Top-10\% Cross-holding & 2023 & 0.581 & 0.690 & 0.367 & 0.938 & 1.473 & 1.884 & 2.953 & $<0.001$ & $<0.001$ \\
\hline Top-20\% Cross-holding & 2023 & 0.242 & 0.384 & 0.000 & 0.387 & 0.875 & 1.086 & 1.516 & $<0.001$ & $<0.001$ \\
\hline Median Cross-holding & 2023 & 0.025 & 0.105 & 0.000 & 0.000 & 0.025 & 0.155 & 0.629 & $<0.001$ & $<0.001$ \\
\hline \multicolumn{11}{|c|}{ II. Cross-holding by All Bidder Shareholders } \\
\hline Top-1\% Cross-holding & 2427 & 2.194 & 2.530 & 1.388 & 2.952 & 5.259 & 7.147 & 11.465 & $<0.001$ & $<0.001$ \\
\hline Top-5\% Cross-holding & 2427 & 0.512 & 0.693 & 0.167 & 0.870 & 1.437 & 1.856 & 2.880 & $<0.001$ & $<0.001$ \\
\hline Top-10\% Cross-holding & 2427 & 0.208 & 0.378 & 0.000 & 0.277 & 0.799 & 1.061 & 1.533 & $<0.001$ & $<0.001$ \\
\hline Top- $20 \%$ Cross-holding & 2427 & 0.059 & 0.182 & 0.000 & 0.000 & 0.177 & 0.452 & 0.940 & $<0.001$ & $<0.001$ \\
\hline Median Cross-holding & 2427 & 0.001 & 0.013 & 0.000 & 0.000 & 0.000 & 0.000 & 0.012 & 0.016 & 0.326 \\
\hline
\end{tabular}


Table 7

\section{Cross-holdings and Synergies}

The sample consists of 897 completed acquisitions announced during the period January 1, 1984, to December 31, 2002. The bidders and targets are listed in the SDC's Mergers and Acquisitions database and have institutional holding data in the CDA/Spectrum database. We keep an acquisition if the bidder owns more than 90 percent of the target after the deal completion. All dollar amounts are in 2002 millions of dollars, all percentages are in real numbers. We further require that the relative size of the deal is no less than 5 percent and the total institutional ownership in the bidder is no less than 20 percent. Columns (1)-(2), (3)-(4), and (5)-(6) are regression results using industry-adjusted one-year, two-year, and three-year post-merger annualized returns on assets, respectively, as the dependent variables. Pre-merger firm characteristics as explanatory variables are also industry-adjusted. All model specifications employ robust standard errors. Superscripts $* * *, * *$, and $*$ correspond to statistical significance at the 1,5 , and 10 percent levels, respectively. P-values are reported in brackets.

\begin{tabular}{|c|c|c|c|c|c|c|}
\hline & $\begin{array}{c}(1) \\
\text { One-year } \\
\text { ROA }\end{array}$ & $\begin{array}{c}(2) \\
\text { One-year } \\
\text { ROA }\end{array}$ & $\begin{array}{c}(3) \\
\text { Two-year } \\
\text { ROA }\end{array}$ & $\begin{array}{c}(4) \\
\text { Two-year } \\
\text { ROA }\end{array}$ & $\begin{array}{c}(5) \\
\text { Three-year } \\
\text { ROA }\end{array}$ & $\begin{array}{c}(6) \\
\text { Three-year } \\
\text { ROA }\end{array}$ \\
\hline Bidder Top- $20 \%$ Cross-holding & $\begin{array}{l}-0.011 \\
{[0.304]}\end{array}$ & & $\begin{array}{l}-0.017 * \\
{[0.072]}\end{array}$ & & $\begin{array}{l}-0.020^{* *} \\
{[0.019]}\end{array}$ & \\
\hline Bidder Median Cross-holding & & $\begin{array}{c}0.009 \\
{[0.699]}\end{array}$ & & $\begin{array}{c}0.003 \\
{[0.912]}\end{array}$ & & $\begin{array}{c}0.001 \\
{[0.964]}\end{array}$ \\
\hline All Cash & $\begin{array}{c}0.015 \\
{[0.198]}\end{array}$ & $\begin{array}{c}0.017 \\
{[0.132]}\end{array}$ & $\begin{array}{c}0.014 \\
{[0.195]}\end{array}$ & $\begin{array}{c}0.017 \\
{[0.120]}\end{array}$ & $\begin{array}{c}0.014 \\
{[0.174]}\end{array}$ & $\begin{array}{r}0.017^{*} \\
{[0.094]}\end{array}$ \\
\hline All Stock & $\begin{array}{c}0.022 * * \\
{[0.025]}\end{array}$ & $\begin{array}{l}0.022 * * \\
{[0.027]}\end{array}$ & $\begin{array}{l}0.022 * * * \\
{[0.006]}\end{array}$ & $\begin{array}{l}0.022 * * * \\
{[0.007]}\end{array}$ & $\begin{array}{l}0.021 * * * \\
{[0.004]}\end{array}$ & $\begin{array}{c}0.021 * * * \\
{[0.005]}\end{array}$ \\
\hline Competing & $\begin{array}{l}-0.027^{*} \\
{[0.085]}\end{array}$ & $\begin{array}{l}-0.027^{*} \\
{[0.085]}\end{array}$ & $\begin{array}{l}-0.021 \\
{[0.186]}\end{array}$ & $\begin{array}{l}-0.020 \\
{[0.190]}\end{array}$ & $\begin{array}{l}-0.017 \\
{[0.223]}\end{array}$ & $\begin{array}{l}-0.017 \\
{[0.230]}\end{array}$ \\
\hline Diversifying & $\begin{array}{c}0.006 \\
{[0.512]}\end{array}$ & $\begin{array}{c}0.007 \\
{[0.445]}\end{array}$ & $\begin{array}{l}-0.001 \\
{[0.857]}\end{array}$ & $\begin{array}{l}-0.000 \\
{[0.978]}\end{array}$ & $\begin{array}{l}-0.001 \\
{[0.840]}\end{array}$ & $\begin{array}{l}-0.000 \\
{[0.995]}\end{array}$ \\
\hline Relative Size & $\begin{array}{l}-0.008 \\
{[0.556]}\end{array}$ & $\begin{array}{l}-0.012 \\
{[0.359]}\end{array}$ & $\begin{array}{c}0.001 \\
{[0.944]}\end{array}$ & $\begin{array}{l}-0.005 \\
{[0.690]}\end{array}$ & $\begin{array}{c}0.008 \\
{[0.494]}\end{array}$ & $\begin{array}{c}0.002 \\
{[0.882]}\end{array}$ \\
\hline Bidder Total Institutional Ownership & $\begin{array}{c}0.007 \\
{[0.836]}\end{array}$ & $\begin{array}{c}0.015 \\
{[0.635]}\end{array}$ & $\begin{array}{l}-0.007 \\
{[0.780]}\end{array}$ & $\begin{array}{c}0.002 \\
{[0.936]}\end{array}$ & $\begin{array}{l}-0.017 \\
{[0.476]}\end{array}$ & $\begin{array}{l}-0.006 \\
{[0.780]}\end{array}$ \\
\hline Bidder Market Capitalization & $\begin{array}{c}0.004 \\
{[0.126]}\end{array}$ & $\begin{array}{c}0.002 \\
{[0.395]}\end{array}$ & $\begin{array}{c}0.005^{* *} \\
{[0.047]}\end{array}$ & $\begin{array}{c}0.003 \\
{[0.258]}\end{array}$ & $\begin{array}{c}0.006^{* *} \\
{[0.011]}\end{array}$ & $\begin{array}{c}0.003 \\
{[0.130]}\end{array}$ \\
\hline Bidder Market Leverage & $\begin{array}{l}0.110^{* *} \\
{[0.020]}\end{array}$ & $\begin{array}{c}0.106 * * \\
{[0.023]}\end{array}$ & $\begin{array}{l}0.102 * * * \\
{[0.002]}\end{array}$ & $\begin{array}{l}0.098 * * * \\
{[0.002]}\end{array}$ & $\begin{array}{c}0.102 * * * \\
{[<0.001]}\end{array}$ & $\begin{array}{l}0.097 * * * \\
{[<0.001]}\end{array}$ \\
\hline Bidder Market- to-Book Ratio & $\begin{array}{c}0.002 \\
{[0.280]}\end{array}$ & $\begin{array}{c}0.002 \\
{[0.267]}\end{array}$ & $\begin{array}{c}0.002 \\
{[0.424]}\end{array}$ & $\begin{array}{c}0.002 \\
{[0.403]}\end{array}$ & $\begin{array}{c}0.001 \\
{[0.482]}\end{array}$ & $\begin{array}{c}0.001 \\
{[0.451]}\end{array}$ \\
\hline Bidder Return on Assets & $\begin{array}{c}0.300^{* * *} \\
{[<0.001]}\end{array}$ & $\begin{array}{c}0.302 * * * \\
{[<0.001]}\end{array}$ & $\begin{array}{c}0.280 * * * \\
{[<0.001]}\end{array}$ & $\begin{array}{c}0.283^{* * *} \\
{[<0.001]}\end{array}$ & $\begin{array}{c}0.277 * * * \\
{[<0.001]}\end{array}$ & $\begin{array}{l}0.281 * * * \\
{[<0.001]}\end{array}$ \\
\hline Intercept & $\begin{array}{l}-0.006 \\
{[0.793]}\end{array}$ & $\begin{array}{l}-0.002 \\
{[0.942]}\end{array}$ & $\begin{array}{l}-0.004 \\
{[0.834]}\end{array}$ & $\begin{array}{c}0.001 \\
{[0.965]}\end{array}$ & $\begin{array}{l}-0.008 \\
{[0.619]}\end{array}$ & $\begin{array}{l}-0.003 \\
{[0.860]}\end{array}$ \\
\hline $\begin{array}{l}\text { Number of Observations } \\
\text { Adjusted R-squared }\end{array}$ & $\begin{array}{c}897 \\
0.151\end{array}$ & $\begin{array}{c}897 \\
0.150\end{array}$ & $\begin{array}{c}897 \\
0.182\end{array}$ & $\begin{array}{c}897 \\
0.179\end{array}$ & $\begin{array}{c}897 \\
0.209\end{array}$ & $\begin{array}{c}897 \\
0.205\end{array}$ \\
\hline
\end{tabular}




\section{Table 8}

\section{The Effects of Cross-holdings on Mergers}

The initial sample consists of 2,815 acquisitions announced during the period January 1, 1984, to December 31, 2002. The bidders and targets are listed in the SDC's Mergers and Acquisitions database and have institutional holding data in the CDA/Spectrum database. We keep an acquisition if the bidder owns less than 50 percent of the target prior to the bid and is seeking to own greater than 50 percent of the target. For completed deals, we require that the bidder owns more than 90 percent of the target after the deal completion. All dollar amounts are in 2002 millions of dollars, all percentages are in real numbers. We further require that the relative size of the deal is no less than 5 percent. Bidder (Target) CAR3 is over days $(-1,1)$, where day 0 is the date of the initial bid announcement by the acquiring firm. Daily abnormal stock returns are computed using the market model and the value-weighted CRSP index. The estimation window is days $(-200,-60)$ prior to the acquisition announcement date. Premium is the ratio of the final offer price to the target's trading price four weeks prior to the original announcement date minus one. Complete is an indicator variable taking the value of one if the deal is completed, and zero otherwise. Crossholdings are defined as the ratio of the shareholder's percentage ownership in the target divided by her percentage ownership in the bidder. Bidder (Target) Top-20\% (Median) Cross-holding is the (marginal) cross-holding for the top 20 (50) percent of institutional shareholdings. Complete, All Cash, All Stock, Competing, and Diversifying are dummy variables that take the value of one for completed acquisitions, if only cash is used to pay for the acquisition, if only equity is used, if there are multiple bids for the same target within one year, if the bidder and target are from two different industries, respectively, and zero otherwise. Relative Size is the transaction value divided by the market value of bidder assets at the end of the fiscal year prior to the bid announcement. Bidder (Target) Total Institutional Ownership is the fraction of a bidder's (target's) stock that is owned by institutional investors. All accounting values are obtained at the fiscal year-end prior to the announcement of the bid. Columns (1)-(2) are regression results based on a sample of deals where the total institutional ownership in the bidder is no less than 20 percent. Columns (3)-(4) are regression results based on a sample of deals where both bidder and target total institutional ownership are no less than 20 percent. All model specifications include year and industry fixed effects and employ robust standard errors. Superscripts $* * *, * *$, and * correspond to statistical significance at the 1, 5, and 10 percent levels, respectively. P-values are reported in brackets. 
Panel A: The Bidder Announcement Period Return

\begin{tabular}{|c|c|c|c|c|}
\hline & $\begin{array}{c}(1) \\
\text { Bidder CAR3 } \\
\end{array}$ & $\begin{array}{c}(2) \\
\text { Bidder CAR3 } \\
\end{array}$ & $\begin{array}{c}\text { (3) } \\
\text { Bidder CAR3 } \\
\end{array}$ & $\begin{array}{c}(4) \\
\text { Bidder CAR3 } \\
\end{array}$ \\
\hline Bidder Top- $20 \%$ Cross-holding & $\begin{array}{c}0.008 \\
{[0.208]}\end{array}$ & & $\begin{array}{c}0.005 \\
{[0.586]}\end{array}$ & \\
\hline Bidder Median Cross-holding & & $\begin{array}{l}-0.001 \\
{[0.960]}\end{array}$ & & $\begin{array}{l}-0.025 \\
{[0.135]}\end{array}$ \\
\hline Target Top- $20 \%$ Cross-holding & & & $\begin{array}{c}0.002 \\
{[0.803]}\end{array}$ & \\
\hline Target Median Cross-holding & & & & $\begin{array}{c}0.033 * \\
{[0.075]}\end{array}$ \\
\hline All Cash & $\begin{array}{c}0.017 * * * \\
{[0.005]}\end{array}$ & $\begin{array}{c}0.016^{* * *} \\
{[0.006]}\end{array}$ & $\begin{array}{c}0.021 * * * \\
{[0.002]}\end{array}$ & $\begin{array}{l}0.020 * * * \\
{[0.002]}\end{array}$ \\
\hline All Stock & $\begin{array}{l}-0.014^{* *} \\
{[0.016]}\end{array}$ & $\begin{array}{l}-0.014^{* *} \\
{[0.018]}\end{array}$ & $\begin{array}{l}-0.011^{*} \\
{[0.083]}\end{array}$ & $\begin{array}{l}-0.011^{*} \\
{[0.072]}\end{array}$ \\
\hline Competing & $\begin{array}{c}0.000 \\
{[0.989]}\end{array}$ & $\begin{array}{c}0.000 \\
{[1.000]}\end{array}$ & $\begin{array}{l}-0.001 \\
{[0.836]}\end{array}$ & $\begin{array}{l}-0.002 \\
{[0.809]}\end{array}$ \\
\hline Diversifying & $\begin{array}{c}0.001 \\
{[0.810]}\end{array}$ & $\begin{array}{c}0.001 \\
{[0.877]}\end{array}$ & $\begin{array}{c}0.001 \\
{[0.851]}\end{array}$ & $\begin{array}{c}0.001 \\
{[0.861]}\end{array}$ \\
\hline Relative Size & $\begin{array}{l}-0.007 \\
{[0.150]}\end{array}$ & $\begin{array}{l}-0.008 \\
{[0.122]}\end{array}$ & $\begin{array}{l}-0.009 \\
{[0.163]}\end{array}$ & $\begin{array}{l}-0.009 \\
{[0.134]}\end{array}$ \\
\hline Bidder Total Institutional Ownership & $\begin{array}{c}0.007 \\
{[0.667]}\end{array}$ & $\begin{array}{c}0.000 \\
{[0.987]}\end{array}$ & $\begin{array}{l}-0.005 \\
{[0.829]}\end{array}$ & $\begin{array}{l}-0.019 \\
{[0.334]}\end{array}$ \\
\hline Target Total Institutional Ownership & $\begin{array}{c}0.003 \\
{[0.853]}\end{array}$ & $\begin{array}{c}0.010 \\
{[0.518]}\end{array}$ & $\begin{array}{c}0.016 \\
{[0.470]}\end{array}$ & $\begin{array}{c}0.030 \\
{[0.122]}\end{array}$ \\
\hline Bidder Market Capitalization & $\begin{array}{c}0.006 \\
{[0.109]}\end{array}$ & $\begin{array}{c}0.005 \\
{[0.115]}\end{array}$ & $\begin{array}{c}0.004 \\
{[0.295]}\end{array}$ & $\begin{array}{c}0.004 \\
{[0.291]}\end{array}$ \\
\hline Target Market Capitalization & $\begin{array}{l}-0.009 * * \\
{[0.021]}\end{array}$ & $\begin{array}{l}-0.008^{* *} \\
{[0.034]}\end{array}$ & $\begin{array}{l}-0.008^{*} \\
{[0.070]}\end{array}$ & $\begin{array}{l}-0.007^{*} \\
{[0.075]}\end{array}$ \\
\hline Bidder Market Leverage & $\begin{array}{c}0.017 \\
{[0.452]}\end{array}$ & $\begin{array}{c}0.016 \\
{[0.472]}\end{array}$ & $\begin{array}{c}0.023 \\
{[0.352]}\end{array}$ & $\begin{array}{c}0.023 \\
{[0.369]}\end{array}$ \\
\hline Bidder Market-to-Book Ratio & $\begin{array}{l}-0.003^{*} \\
{[0.066]}\end{array}$ & $\begin{array}{l}-0.003^{*} \\
{[0.061]}\end{array}$ & $\begin{array}{l}-0.003^{*} \\
{[0.068]}\end{array}$ & $\begin{array}{l}-0.003^{*} \\
{[0.054]}\end{array}$ \\
\hline Bidder Return on Assets & $\begin{array}{l}-0.008 \\
{[0.660]}\end{array}$ & $\begin{array}{l}-0.009 \\
{[0.632]}\end{array}$ & $\begin{array}{l}-0.002 \\
{[0.913]}\end{array}$ & $\begin{array}{l}-0.002 \\
{[0.924]}\end{array}$ \\
\hline Bidder Prior Year Stock Return & $\begin{array}{l}-0.002 \\
{[0.535]}\end{array}$ & $\begin{array}{l}-0.002 \\
{[0.572]}\end{array}$ & $\begin{array}{c}0.002 \\
{[0.654]}\end{array}$ & $\begin{array}{c}0.002 \\
{[0.638]}\end{array}$ \\
\hline Intercept & $\begin{array}{l}-0.015 \\
{[0.471]}\end{array}$ & $\begin{array}{l}-0.017 \\
{[0.434]}\end{array}$ & $\begin{array}{l}-0.025 \\
{[0.275]}\end{array}$ & $\begin{array}{l}-0.024 \\
{[0.297]}\end{array}$ \\
\hline Yr, Ind. Dummies & Yes & Yes & Yes & Yes \\
\hline Number of Observations & 1379 & 1379 & 1071 & 1071 \\
\hline Adjusted R-squared & 0.075 & 0.074 & 0.079 & 0.082 \\
\hline
\end{tabular}


Panel B: The Target Announcement Period Return

\begin{tabular}{|c|c|c|c|c|}
\hline & $\begin{array}{c}(1) \\
\text { Target CAR3 }\end{array}$ & $\begin{array}{c}(2) \\
\text { Target CAR3 }\end{array}$ & $\begin{array}{c}(3) \\
\text { Target CAR3 }\end{array}$ & $\begin{array}{c}(4) \\
\text { Target CAR3 }\end{array}$ \\
\hline Bidder Top- $20 \%$ Cross-holding & $\begin{array}{l}-0.012 \\
{[0.483]}\end{array}$ & & $\begin{array}{c}0.012 \\
{[0.556]}\end{array}$ & \\
\hline Bidder Median Cross-holding & & $\begin{array}{l}-0.037 \\
{[0.227]}\end{array}$ & & $\begin{array}{l}-0.051 \\
{[0.157]}\end{array}$ \\
\hline Target Top- $20 \%$ Cross-holding & & & $\begin{array}{l}-0.042 * * \\
{[0.036]}\end{array}$ & \\
\hline Target Median Cross-holding & & & & $\begin{array}{l}-0.007 \\
{[0.864]}\end{array}$ \\
\hline All Cash & $\begin{array}{l}0.041 * * \\
{[0.028]}\end{array}$ & $\begin{array}{c}0.042 * * \\
{[0.026]}\end{array}$ & $\begin{array}{c}0.048 * * \\
{[0.016]}\end{array}$ & $\begin{array}{l}0.049^{* *} \\
{[0.014]}\end{array}$ \\
\hline All Stock & $\begin{array}{l}-0.024^{*} \\
{[0.079]}\end{array}$ & $\begin{array}{l}-0.024^{*} \\
{[0.081]}\end{array}$ & $\begin{array}{l}-0.037 * * \\
{[0.013]}\end{array}$ & $\begin{array}{l}-0.035^{* *} \\
{[0.017]}\end{array}$ \\
\hline Competing & $\begin{array}{l}-0.027 * * \\
{[0.046]}\end{array}$ & $\begin{array}{l}-0.026 * * \\
{[0.049]}\end{array}$ & $\begin{array}{l}-0.025^{*} \\
{[0.092]}\end{array}$ & $\begin{array}{l}-0.024 \\
{[0.105]}\end{array}$ \\
\hline Diversifying & $\begin{array}{l}-0.023^{*} \\
{[0.060]}\end{array}$ & $\begin{array}{l}-0.023^{*} \\
{[0.063]}\end{array}$ & $\begin{array}{l}-0.027 * * \\
{[0.039]}\end{array}$ & $\begin{array}{l}-0.025^{*} \\
{[0.059]}\end{array}$ \\
\hline Relative Size & $\begin{array}{c}0.016^{*} \\
{[0.085]}\end{array}$ & $\begin{array}{r}0.016^{*} \\
{[0.078]}\end{array}$ & $\begin{array}{c}0.007 \\
{[0.513]}\end{array}$ & $\begin{array}{c}0.007 \\
{[0.498]}\end{array}$ \\
\hline Bidder Total Institutional Ownership & $\begin{array}{c}0.017 \\
{[0.674]}\end{array}$ & $\begin{array}{c}0.018 \\
{[0.660]}\end{array}$ & $\begin{array}{c}0.087^{*} \\
{[0.086]}\end{array}$ & $\begin{array}{c}0.036 \\
{[0.467]}\end{array}$ \\
\hline Target Total Institutional Ownership & $\begin{array}{c}0.042 \\
{[0.273]}\end{array}$ & $\begin{array}{c}0.035 \\
{[0.316]}\end{array}$ & $\begin{array}{l}0.021 \\
{[0.695]}\end{array}$ & $\begin{array}{l}0.065 \\
{[0.171]}\end{array}$ \\
\hline Bidder Market Capitalization & $\begin{array}{c}0.052^{* * * *} \\
{[<0.001]}\end{array}$ & $\begin{array}{c}0.052^{* * * *} \\
{[<0.001]}\end{array}$ & $\begin{array}{c}0.041 * * * \\
{[<0.001]}\end{array}$ & $\begin{array}{c}0.043^{* * *} \\
{[<0.001]}\end{array}$ \\
\hline Target Market Capitalization & $\begin{array}{l}-0.050^{* * *} \\
{[<0.001]}\end{array}$ & $\begin{array}{l}-0.050^{* * * *} \\
{[<0.001]}\end{array}$ & $\begin{array}{l}-0.036^{* * *} \\
{[<0.001]}\end{array}$ & $\begin{array}{l}-0.038^{* * *} \\
{[<0.001]}\end{array}$ \\
\hline Target Market Leverage & $\begin{array}{c}0.022 \\
{[0.624]}\end{array}$ & $\begin{array}{c}0.022 \\
{[0.624]}\end{array}$ & $\begin{array}{c}0.007 \\
{[0.904]}\end{array}$ & $\begin{array}{c}0.018 \\
{[0.738]}\end{array}$ \\
\hline Target Market-to-Book Ratio & $\begin{array}{l}-0.008 * * \\
{[0.015]}\end{array}$ & $\begin{array}{l}-0.008 * * \\
{[0.016]}\end{array}$ & $\begin{array}{l}-0.009 * * \\
{[0.022]}\end{array}$ & $\begin{array}{l}-0.008 * * \\
{[0.029]}\end{array}$ \\
\hline Target Return on Assets & $\begin{array}{c}0.051 \\
{[0.151]}\end{array}$ & $\begin{array}{c}0.051 \\
{[0.147]}\end{array}$ & $\begin{array}{c}0.047 \\
{[0.255]}\end{array}$ & $\begin{array}{c}0.052 \\
{[0.199]}\end{array}$ \\
\hline Target Prior Year Stock Return & $\begin{array}{l}-0.044 * * * \\
{[<0.001]}\end{array}$ & $\begin{array}{l}-0.045^{* * * *} \\
{[<0.001]}\end{array}$ & $\begin{array}{l}-0.037 * * * \\
{[0.002]}\end{array}$ & $\begin{array}{l}-0.038^{* * * *} \\
{[0.001]}\end{array}$ \\
\hline Intercept & $\begin{array}{l}0.138^{* * *} \\
{[0.009]}\end{array}$ & $\begin{array}{l}0.132 * * \\
{[0.012]}\end{array}$ & $\begin{array}{c}0.040 \\
{[0.463]}\end{array}$ & $\begin{array}{c}0.033 \\
{[0.544]}\end{array}$ \\
\hline $\begin{array}{l}\text { Yr, Ind. Dummies } \\
\text { Number of Observations } \\
\text { Adjusted R-squared }\end{array}$ & $\begin{array}{c}\text { Yes } \\
1381 \\
0.151\end{array}$ & $\begin{array}{c}\text { Yes } \\
1381 \\
0.151\end{array}$ & $\begin{array}{c}\text { Yes } \\
1072 \\
0.164\end{array}$ & $\begin{array}{c}\text { Yes } \\
1072 \\
0.162\end{array}$ \\
\hline
\end{tabular}


Panel C: The Bid Premium

\begin{tabular}{|c|c|c|c|c|}
\hline & $\begin{array}{c}(1) \\
\text { Premium }\end{array}$ & $\begin{array}{c}(2) \\
\text { Premium } \\
\end{array}$ & $\begin{array}{c}(3) \\
\text { Premium } \\
\end{array}$ & $\begin{array}{c}(4) \\
\text { Premium }\end{array}$ \\
\hline Bidder Top-20\% Cross-holding & $\begin{array}{l}-0.013 \\
{[0.655]}\end{array}$ & & $\begin{array}{c}0.050 \\
{[0.114]}\end{array}$ & \\
\hline Bidder Median Cross-holding & & $\begin{array}{c}0.024 \\
{[0.651]}\end{array}$ & & $\begin{array}{c}0.030 \\
{[0.614]}\end{array}$ \\
\hline Target Top- $20 \%$ Cross-holding & & & $\begin{array}{l}-0.098 * * * \\
{[0.005]}\end{array}$ & \\
\hline Target Median Cross-holding & & & & $\begin{array}{l}-0.072 \\
{[0.279]}\end{array}$ \\
\hline All Cash & $\begin{array}{c}0.010 \\
{[0.761]}\end{array}$ & $\begin{array}{c}0.011 \\
{[0.742]}\end{array}$ & $\begin{array}{c}0.026 \\
{[0.361]}\end{array}$ & $\begin{array}{c}0.027 \\
{[0.352]}\end{array}$ \\
\hline All Stock & $\begin{array}{l}-0.020 \\
{[0.451]}\end{array}$ & $\begin{array}{l}-0.021 \\
{[0.444]}\end{array}$ & $\begin{array}{l}-0.034 \\
{[0.150]}\end{array}$ & $\begin{array}{l}-0.032 \\
{[0.174]}\end{array}$ \\
\hline Competing & $\begin{array}{c}0.023 \\
{[0.396]}\end{array}$ & $\begin{array}{c}0.023 \\
{[0.395]}\end{array}$ & $\begin{array}{c}0.040 \\
{[0.155]}\end{array}$ & $\begin{array}{c}0.042 \\
{[0.139]}\end{array}$ \\
\hline Diversifying & $\begin{array}{l}-0.030 \\
{[0.170]}\end{array}$ & $\begin{array}{l}-0.030 \\
{[0.176]}\end{array}$ & $\begin{array}{l}-0.018 \\
{[0.410]}\end{array}$ & $\begin{array}{l}-0.016 \\
{[0.466]}\end{array}$ \\
\hline Relative Size & $\begin{array}{c}0.091 * * * \\
{[<0.001]}\end{array}$ & $\begin{array}{c}0.092^{* * *} \\
{[<0.001]}\end{array}$ & $\begin{array}{c}0.081 * * * \\
{[<0.001]}\end{array}$ & $\begin{array}{c}0.082 * * * \\
{[<0.001]}\end{array}$ \\
\hline Bidder Total Institutional Ownership & $\begin{array}{l}-0.015 \\
{[0.853]}\end{array}$ & $\begin{array}{c}0.001 \\
{[0.986]}\end{array}$ & $\begin{array}{l}0.255^{* * *} \\
{[0.002]}\end{array}$ & $\begin{array}{c}0.167^{* *} \\
{[0.024]}\end{array}$ \\
\hline Target Total Institutional Ownership & $\begin{array}{l}-0.040 \\
{[0.563]}\end{array}$ & $\begin{array}{l}-0.053 \\
{[0.428]}\end{array}$ & $\begin{array}{l}-0.104 \\
{[0.218]}\end{array}$ & $\begin{array}{l}-0.013 \\
{[0.868]}\end{array}$ \\
\hline Bidder Market Capitalization & $\begin{array}{c}0.093 * * * \\
{[<0.001]}\end{array}$ & $\begin{array}{c}0.093^{* * *} \\
{[<0.001]}\end{array}$ & $\begin{array}{c}0.080 * * * \\
{[<0.001]}\end{array}$ & $\begin{array}{c}0.085^{* * *} \\
{[<0.001]}\end{array}$ \\
\hline Target Market Capitalization & $\begin{array}{l}-0.112^{* * *} \\
{[<0.001]}\end{array}$ & $\begin{array}{l}-0.114^{* * * *} \\
{[<0.001]}\end{array}$ & $\begin{array}{l}-0.097^{* * *} \\
{[<0.001]}\end{array}$ & $\begin{array}{l}-0.105^{* * *} \\
{[<0.001]}\end{array}$ \\
\hline Bidder Market Leverage & $\begin{array}{c}0.099 \\
{[0.383]}\end{array}$ & $\begin{array}{c}0.100 \\
{[0.380]}\end{array}$ & $\begin{array}{c}0.039 \\
{[0.675]}\end{array}$ & $\begin{array}{c}0.063 \\
{[0.492]}\end{array}$ \\
\hline Bidder Market-to-Book Ratio & $\begin{array}{c}0.002 \\
{[0.723]}\end{array}$ & $\begin{array}{c}0.002 \\
{[0.713]}\end{array}$ & $\begin{array}{c}0.008^{* *} \\
{[0.038]}\end{array}$ & $\begin{array}{c}0.009 * * \\
{[0.027]}\end{array}$ \\
\hline Bidder Return on Assets & $\begin{array}{c}0.015 \\
{[0.837]}\end{array}$ & $\begin{array}{c}0.016 \\
{[0.829]}\end{array}$ & $\begin{array}{l}-0.053 \\
{[0.474]}\end{array}$ & $\begin{array}{l}-0.044 \\
{[0.564]}\end{array}$ \\
\hline Bidder Prior Year Stock Return & $\begin{array}{c}0.024 \\
{[0.206]}\end{array}$ & $\begin{array}{c}0.024 \\
{[0.206]}\end{array}$ & $\begin{array}{l}-0.001 \\
{[0.960]}\end{array}$ & $\begin{array}{l}-0.002 \\
{[0.899]}\end{array}$ \\
\hline Intercept & $\begin{array}{c}0.454^{* * * *} \\
{[<0.001]}\end{array}$ & $\begin{array}{c}0.460^{* * *} \\
{[<0.001]}\end{array}$ & $\begin{array}{l}0.265^{* * * *} \\
{[0.001]}\end{array}$ & $\begin{array}{l}0.268^{* * *} \\
{[0.001]}\end{array}$ \\
\hline $\begin{array}{l}\text { Yr, Ind. Dummies } \\
\text { Number of Observations } \\
\text { Adjusted R-squared }\end{array}$ & $\begin{array}{c}\text { Yes } \\
1337 \\
0.121\end{array}$ & $\begin{array}{c}\text { Yes } \\
1337 \\
0.121\end{array}$ & $\begin{array}{l}\text { Yes } \\
1051 \\
0.160\end{array}$ & $\begin{array}{l}\text { Yes } \\
1051 \\
0.153\end{array}$ \\
\hline
\end{tabular}




\section{Panel D: The Completion Likelihood}

\begin{tabular}{|c|c|c|c|c|}
\hline & $\begin{array}{c}\text { (1) } \\
\text { Complete }\end{array}$ & $\begin{array}{c}\text { (2) } \\
\text { Complete }\end{array}$ & $\begin{array}{c}\text { (3) } \\
\text { Complete }\end{array}$ & $\begin{array}{c}\text { (4) } \\
\text { Complete }\end{array}$ \\
\hline Bidder Top- $20 \%$ Cross-holding & $\begin{array}{c}0.074 \\
{[0.544]}\end{array}$ & & $\begin{array}{c}0.246 \\
{[0.133]}\end{array}$ & \\
\hline Bidder Median Cross-holding & & $\begin{array}{c}0.034 \\
{[0.898]}\end{array}$ & & $\begin{array}{l}-0.068 \\
{[0.842]}\end{array}$ \\
\hline Target Top- $20 \%$ Cross-holding & & & $\begin{array}{l}-0.167 \\
{[0.301]}\end{array}$ & \\
\hline Target Median Cross-holding & & & & $\begin{array}{c}0.517 \\
{[0.211]}\end{array}$ \\
\hline Premium & $\begin{array}{c}0.042 \\
{[0.701]}\end{array}$ & $\begin{array}{c}0.040 \\
{[0.711]}\end{array}$ & $\begin{array}{c}0.062 \\
{[0.719]}\end{array}$ & $\begin{array}{c}0.082 \\
{[0.634]}\end{array}$ \\
\hline All Cash & $\begin{array}{l}-0.469^{* * *} \\
{[<0.001]}\end{array}$ & $\begin{array}{l}-0.473^{* * *} \\
{[<0.001]}\end{array}$ & $\begin{array}{l}-0.481 * * * \\
{[0.001]}\end{array}$ & $\begin{array}{c}-0.489^{* * *} \\
{[<0.001]}\end{array}$ \\
\hline All Stock & $\begin{array}{l}-0.031 \\
{[0.781]}\end{array}$ & $\begin{array}{l}-0.029 \\
{[0.797]}\end{array}$ & $\begin{array}{l}-0.057 \\
{[0.651]}\end{array}$ & $\begin{array}{l}-0.059 \\
{[0.643]}\end{array}$ \\
\hline Competing & $\begin{array}{l}-1.169^{* * *} \\
{[<0.001]}\end{array}$ & $\begin{array}{l}-1.169^{* * *} \\
{[<0.001]}\end{array}$ & $\begin{array}{l}-1.259^{* * *} \\
{[<0.001]}\end{array}$ & $\begin{array}{l}-1.263^{* * *} \\
{[<0.001]}\end{array}$ \\
\hline Diversifying & $\begin{array}{c}0.109 \\
{[0.243]}\end{array}$ & $\begin{array}{c}0.104 \\
{[0.266]}\end{array}$ & $\begin{array}{c}0.151 \\
{[0.173]}\end{array}$ & $\begin{array}{c}0.153 \\
{[0.167]}\end{array}$ \\
\hline Relative Size & $\begin{array}{l}-0.038 \\
{[0.560]}\end{array}$ & $\begin{array}{l}-0.042 \\
{[0.515]}\end{array}$ & $\begin{array}{c}0.002 \\
{[0.977]}\end{array}$ & $\begin{array}{l}-0.003 \\
{[0.968]}\end{array}$ \\
\hline Bidder Total Institutional Ownership & $\begin{array}{c}0.737 * * \\
{[0.019]}\end{array}$ & $\begin{array}{c}0.683 * * \\
{[0.023]}\end{array}$ & $\begin{array}{c}0.875^{* *} * \\
{[0.034]}\end{array}$ & $\begin{array}{c}0.463 \\
{[0.204]}\end{array}$ \\
\hline Target Total Institutional Ownership & $\begin{array}{l}-0.074 \\
{[0.787]}\end{array}$ & $\begin{array}{l}-0.012 \\
{[0.962]}\end{array}$ & $\begin{array}{l}-0.567 \\
{[0.168]}\end{array}$ & $\begin{array}{l}-0.092 \\
{[0.794]}\end{array}$ \\
\hline Bidder Market Capitalization & $\begin{array}{c}0.301^{* * *} \\
{[<0.001]}\end{array}$ & $\begin{array}{c}0.300^{* * *} \\
{[<0.001]}\end{array}$ & $\begin{array}{c}0.351 * * * \\
{[<0.001]}\end{array}$ & $\begin{array}{c}0.355^{* * *} \\
{[<0.001]}\end{array}$ \\
\hline Target Market Capitalization & $\begin{array}{l}-0.279^{* * *} \\
{[<0.001]}\end{array}$ & $\begin{array}{l}-0.271^{* * *} \\
{[<0.001]}\end{array}$ & $\begin{array}{l}-0.365^{* * *} \\
{[<0.001]}\end{array}$ & $\begin{array}{l}-0.382 * * * \\
{[<0.001]}\end{array}$ \\
\hline Bidder Market Leverage & $\begin{array}{c}0.145 \\
{[0.711]}\end{array}$ & $\begin{array}{c}0.140 \\
{[0.720]}\end{array}$ & $\begin{array}{c}0.108 \\
{[0.821]}\end{array}$ & $\begin{array}{c}0.132 \\
{[0.780]}\end{array}$ \\
\hline Bidder Market-to-Book Ratio & $\begin{array}{l}-0.005 \\
{[0.843]}\end{array}$ & $\begin{array}{l}-0.005 \\
{[0.818]}\end{array}$ & $\begin{array}{c}0.013 \\
{[0.647]}\end{array}$ & $\begin{array}{c}0.010 \\
{[0.733]}\end{array}$ \\
\hline Bidder Return on Assets & $\begin{array}{l}-0.285 \\
{[0.260]}\end{array}$ & $\begin{array}{l}-0.292 \\
{[0.249]}\end{array}$ & $\begin{array}{c}0.065 \\
{[0.817]}\end{array}$ & $\begin{array}{c}0.086 \\
{[0.760]}\end{array}$ \\
\hline Bidder Prior Year Stock Return & $\begin{array}{c}0.089 \\
{[0.178]}\end{array}$ & $\begin{array}{c}0.091 \\
{[0.171]}\end{array}$ & $\begin{array}{r}0.150^{*} \\
{[0.074]}\end{array}$ & $\begin{array}{c}0.152^{*} \\
{[0.068]}\end{array}$ \\
\hline Intercept & $\begin{array}{c}6.271^{* * *} \\
{[<0.001]}\end{array}$ & $\begin{array}{c}6.265^{* * *} \\
{[<0.001]}\end{array}$ & $\begin{array}{c}6.342 * * * \\
{[<0.001]}\end{array}$ & $\begin{array}{c}6.435^{* * *} \\
{[<0.001]}\end{array}$ \\
\hline $\begin{array}{l}\text { Yr, Ind. Dummies } \\
\text { Number of Observations } \\
\text { Pseudo R-squared }\end{array}$ & $\begin{array}{l}\text { Yes } \\
1316 \\
0.205\end{array}$ & $\begin{array}{l}\text { Yes } \\
1316 \\
0.204\end{array}$ & $\begin{array}{c}\text { Yes } \\
1035 \\
0.240\end{array}$ & $\begin{array}{l}\text { Yes } \\
1035 \\
0.240\end{array}$ \\
\hline
\end{tabular}




\section{Table 9}

\section{Cross-holdings and Managerial Incentives}

The sample consists of 1,179 acquisitions announced during the period January 1, 1984, to December 31, 2002 with available data on measures of corporate governance. The bidders and targets are listed in the SDC's Mergers and Acquisitions database and have institutional holding data in the CDA/Spectrum database. We keep an acquisition if the bidder owns less than 50 percent of the target prior to the bid and is seeking to own greater than 50 percent of the target. For completed deals, we require that the bidder owns more than 90 percent of the target after the deal completion. The G-index is defined based on Gompers et al. (2003), and the E-index is defined based on Bebchuk et al. (2006). Superscripts $* * *, * *$, and * correspond to statistical significance at the 1,5 , and 10 percent levels, respectively. P-values are reported in brackets.

\begin{tabular}{|c|c|c|c|c|c|}
\hline & $\begin{array}{c}\text { Bidder Total } \\
\text { Institutional } \\
\text { Ownership } \\
\end{array}$ & $\begin{array}{l}\text { Target Total } \\
\text { Institutional } \\
\text { Ownership } \\
\end{array}$ & $\begin{array}{c}\text { Bidder } \\
\text { Top-20\% } \\
\text { Cross-holding } \\
\end{array}$ & $\begin{array}{c}\text { Bidder } \\
\text { Median } \\
\text { Cross-holding } \\
\end{array}$ & G-index \\
\hline Target Total Institutional Ownership & $\begin{array}{c}0.319^{* * *} \\
{[<0.001]}\end{array}$ & & & & \\
\hline Bidder Top- $20 \%$ Cross-holding & $\begin{array}{l}-0.104 * * * \\
{[<0.001]}\end{array}$ & $\begin{array}{l}0.600 * * * \\
{[<0.001]}\end{array}$ & & & \\
\hline Bidder Median Cross-holding & $\begin{array}{l}-0.061 * * \\
{[0.036]}\end{array}$ & $\begin{array}{c}0.372 * * * \\
{[<0.001]}\end{array}$ & $\begin{array}{l}0.608^{* * *} \\
{[<0.001]}\end{array}$ & & \\
\hline G-index & $\begin{array}{r}0.057^{*} \\
{[0.051]}\end{array}$ & $\begin{array}{l}-0.002 \\
{[0.946]}\end{array}$ & $\begin{array}{l}-0.030 \\
{[0.302]}\end{array}$ & $\begin{array}{l}-0.027 \\
{[0.364]}\end{array}$ & \\
\hline E-index & $\begin{array}{l}-0.004 \\
{[0.899]}\end{array}$ & $\begin{array}{l}-0.125^{* * *} \\
{[<0.001]}\end{array}$ & $\begin{array}{l}-0.114 * * * \\
{[<0.001]}\end{array}$ & $\begin{array}{l}-0.071 * * \\
{[0.015]}\end{array}$ & $\begin{array}{l}0.712 * * * \\
{[<0.001]}\end{array}$ \\
\hline
\end{tabular}

